\title{
LIMITATION OF SALES WARRANTIES AS AN ALTERNATIVE TO INTELLECTUAL PROPERTY RIGHTS: AN EMPIRICAL ANALYSIS OF IPHONE WARRANTIES' DETERRENT IMPACT ON CONSUMERS
}

\author{
MARC L. ROARK ${ }^{1}$
}

\begin{abstract}
Apple's success with the Apple iPhone has brought with it certain problems. Its success has engendered a community that has attempted to circumvent Apple's exclusive service agreement with AT\&T. Unfortunately for Apple (and similarly situated manufacturers), intellectual property law allows consumers to alter their products so as to circumvent relationships that manufacturers may have with others. The patent and copyright law first sale doctrine allows consumers to manipulate a product after it is purchased. As a result, manufacturers are increasingly turning to alternatives to intellectual property to secure control over the device after the sale. One such alternative is the exclusion of warranty under Article 2 of the Uniform Commercial Code.

This iBrief considers whether limitation of warranties have the deterrence effect manufacturers desire. Said differently, it considers whether manufacturers can use warranty limitations to prevent consumers from using their products in an unauthorized manner. The iBrief presents a behavioral model based on the Triandis model of planned behavior and enhances the model by accounting for likely and unlikely benefits and detriments. The model suggests that participants weigh the probability and magnitude of the detriment against the probability and magnitude
\end{abstract}

\footnotetext{
${ }^{1}$ Assistant Professor of Law, University of La Verne College of Law. J.D. Civil Law, Loyola University New Orleans College of Law (2002), LLM, Duke University School of Law. I want to thank my colleagues who have given valuable feedback and critique at every stage of this project, including Dennis Couch, Diane Klein, Thom Lambert, Stacy Strong, Raphael Gely, Jim Levitt, and David Mitchell. I also want to thank my research assistant Jeremy Craven who provided valuable research for this paper. I owe my gratitude to the participants in faculty workshops at the University of Missouri and the University of Kansas for helping make this piece better; any problems in the piece are mine not theirs. Finally, I want to thank the survey participants, whoever you may be, for volunteering your time to respond and provide the empirical data necessary to write this piece.
} 
of the beneficial impact when making the decision to engage in technological piracy. This model, considered with other empirical evidence, suggests that Apple's warranty could be a stronger deterrent for consumers than civil liability. The iBrief concludes that manufacturers can better protect their post-sale expectation of profits by raising consumer awareness of their warranty's quality and by raising awareness of the consequences for using the product in a way that is outside the terms of the consumers' authorized use.

\section{INTRODUCTION}

I1 The Apple iPhone's warranty contains a warning: "Important: Do not open the hardware product. Opening the hardware product may cause damage that is not covered by this warranty. Only Apple or an authorized service provider should perform service on this hardware product."2

q2 That warning is bolstered by a limitation of warranty that provides,

[T] his warranty does not apply to damage caused by service (including upgrades and expansions) performed by anyone who is not a representative of Apple or an Apple Authorized Service Provider; or to a product or part that has been modified to alter functionality or capability without the written permission of Apple. ${ }^{3}$

93 The message is clear: do not tamper with the product or else the warranty is void. This warning is old news to the hacking community, which has developed methods to reprogram the iPhone to function on other cellular phone service providers. ${ }^{4}$ Indeed, hackers well appreciate the fact that altering an iPhone will result in the hacker no longer receiving technological support assistance from Apple, even for the most mundane (and unrelated) problems. ${ }^{5}$

${ }^{2}$ Apple One (1) Year Limited Warranty for iPhone 3G, http://www.apple.com/legal/warranty/iPhone/3g.html (last visited Apr. 2, 2010). ${ }^{3} I d$.

${ }^{4}$ See, e.g., Ryan Block, Phone Unlocked: AT\&T Loses iPhone Exclusivity, ENGADGET (Aug. 24, 2007, 12:00 PM), http://www.engadget.com/2007/08/24/iPhone-unlocked-atandt-loses-iPhoneexclusivity-august-24-2007.

${ }^{5}$ For example, one exchange in an Apple Tech forum asked "I am making a trip to Apple's Genius Bar tomorrow, and I want to know if changing your icons (including system icons) or dock breaks your warranty, like how jailbreaking your iPhone breaks your iPhone's warranty, because I don't want to have to change everything back to default if I don't have to." See danemer, Comment to Does Changing Your Dock or Icons Break Your Warranty?, MACTHEMES FORUM (Oct. 13, 2008, 7:29PM), http://macthemes.net/forum/viewtopic.php?pid=345964. 
94 The conventional wisdom behind these warranty limitation provisions is quite intuitive. These products are highly sophisticated machines, which if altered incorrectly, could cause the device to malfunction. Such malfunctions create causation issues when (1) an individual claims that the product failed on its own accord and the product is then unsuccessfully repaired by an unauthorized agent, or (2) the product is manipulated beyond the intended use. ${ }^{6}$ Thus, companies like Apple have a legal reason for limiting warranty effectiveness to parties who have sought repair from Apple or Apple's authorized affiliates. Warranty limitations, while vexing to consumers, allow companies to moderate their risk and exposure caused by mistreatment of the device or failure to adhere to certain care instructions.

95 There may also be an unintuitive (though intentional) reason behind a company's inclusion of such warranty provisions. Where intellectual property law has stripped manufacturers of the ability to control consumer actions, such limitations of warranties provide an incentive to consumers to honor the company's wishes regarding the product. ${ }^{7}$ In a sense, companies such as Apple resuscitate their control over sold devices-overcoming the control relinquished after the first sale - by tying their warranties to certain conditions. These companies void a customer's warranty for actions such as opening the device, using the device in an unauthorized manner, and seeking repair from non-approved providers. These warranties and service agreements can serve as contractual incentives for consumers to behave in a

${ }^{6}$ Gregory v. White Truck \& Equip. Co., 323 N.E.2d 280, 287 (Ind. Ct. App. 1975) ("A legal description of those acts which constitute a 'misuse' of a product has proven to be difficult to achieve. The problem appears to us to be one of failing to differentiate between misuse of a product which does not exhibit any defective condition until misused, or which does not appear to be defective and unreasonably dangerous, and misuse of a product when the defective and unreasonably dangerous condition is either discovered by the consumer or brought to his attention by a legally sufficient warning. While in either situation a product is being misused, the former constitutes the true category of misuse while the latter form of misuse is tantamount to the traditional concepts of incurred or assumed risk.").

${ }^{7}$ One primary mechanism that strips manufacturers of certain intellectual property rights is the first sale doctrine in Copyright and Patent law. See Quanta Computer, Inc. v. LG Elecs., Inc., 128 S. Ct. 2109, 2122 (2008) ("The authorized sale of an article that substantially embodies a patent exhausts the patent holder's rights and prevents the patent holder from invoking patent law to control post-sale use of the article."); Quality King Distribs., Inc., v. L'Anza Research Int'l, Inc., 523 U.S. 135, 151 (1998) ( "The whole point of the first sale doctrine is that once the copyright owner places a copyrighted item in the stream of commerce by selling it, he has exhausted his exclusive statutory right to control its distribution.”); see also infra Part I.A., notes 28-34, and accompanying text. 
certain manner. If successful, contractual remedies, such as limitations of warranty, effectively allow Apple and its partners to maintain the exclusive financial rewards the iPhone may provide even after the sale.

96 This type of alternative to intellectual property law fits within the broader literature of private remedies for patented and copyrighted products. ${ }^{8}$ The so-called first mover advantage seeks to enable intellectual property rights holders to protect their goods from further exploitation through the use of "contractual agreements, joint ventures, technological opacity, copy-prevention technologies, secrecy practices, and various product branding, bundling, learning by doing, and other commercial strategies that exploit a first-mover innovator's lead time." 9 Indeed, copyright holders find vast alternatives to IP law via licensing practice in other areas of IP practice as well. ${ }^{10}$ Indeed, the similarities between licensing practice and warranty deletion are remarkably similar as Professor James Gibson has pointed out,

The Copyright Doctrines that determine where private entitlement ends and public privilege begins are inherently ambiguous. This means that those who want to make use of copyrighted material cannot make accurate ex ante judgments regarding the need to secure a license [or in the case of voidance of warranties, avoid certain conduct]. Yet making the wrong call can be costly because [of] the penalties . . . better safe than sued. ${ }^{11}$

\footnotetext{
${ }^{8}$ See generally Tom G. Palmer, Intellectual Property: A Non-Posnerian Law and Economics Approach, 12 HAMLINE L. REV. 261, 287-300 (1989). See generally Jonathan M. Barnett, Private Protection of Patentable Goods, 25 CARdOzo L. REV. 1251 (2004); Tom W. Bell, Escape from Copyright: Market Success vs. Statutory Failure in the Protection of Expressive Works, 69 U. CIN. L. REV. 741(2001); Glynn S. Lunney, The Death of Copyright Digital Technology, Private Copying, and the Digital Millenium Copyright Act, 87 VA. L. REV. 813 (2001); Raymond Shih Ray Ku, The Creative Destruction of Copyright: Napster and the New Economics of Digital Technology, 69 U. CHI. L. REV. 263 (2002).

${ }^{9}$ Barnett, supra note 8, at 1252 . Other First mover advantages focus on integrating technology into products to alert the manufacturer or producer of an intended use of the product. See, e.g., Rob Healy, Digital Audio Watermarking for Broadcast Monitoring and content Identification (October 2009) (unpublished masters thesis), available at http://eprints.nuim.ie/1971/1/Thesis FINAL submission 010610.pdf.

${ }^{10}$ For example, copyright holders in the entertainment industry have found that forcing licensing creates a market which disables any fair use defense that might otherwise be sound. See James Gibson, Risk Aversion and Rights Accretion in Intellectual Property Law, 116 YALE L.J. 882, 884 (2007).

${ }^{11} I d$. at 884 .
} 
97 Using warranty limitations, which consider consumer risk aversion, can sabotage a pirate's attempt to manipulate the technology in an unapproved way. ${ }^{12}$ This iBrief, in contrast, considers a bilateral approach that incentivizes consumers not to use the product in an unauthorized way in exchange for certain contractual rights-namely warranties. ${ }^{13}$

q8 So why would companies, such as Apple, be so concerned about restricting access to the inner operations of their products? Simply put, manufacturers believe that the single greatest loss of profit is the unauthorized copying/exploitation of their technology in non-mainstream markets. ${ }^{14}$ Manufacturers expect to reap profit from the growing after-sale

\footnotetext{
${ }^{12}$ For example, various Digital Copyright holders have gained notice by loading "tainted" products on peer-to-peer file sharing services known for Digital Copyright violations in an effort to prevent individuals from obtaining legitimate, but pirated works. See Matthew C. Mousley, Peer to Peer Combat: The Entertainment Industry's Arsenal in its War on Digital Piracy, 48 VILL. L. REV. 667, 689-93 (2003). Apple itself has engaged in combative techniques, utilizing software to disable or "brick" unlocked iPhones. See Katie Hafner, Altered iPhones Freeze Up, N.Y. TIMES, Sept. 29, 2007, at C1; see also Patrick J. Cleary, The Apple Cat and The Fanboy Mouse: Unlocking the Apple iPhone, 9 N.C. J.L. \& TECH. 295, 298 (2008).

${ }^{13}$ In referring to bilateral approaches, I mean not the traditional common law view of bilateral agreements as types of assent to promises made, but rather the civil law view reflecting the obligation as two mutually bargained for performances by the parties. Compare E. Allen Farnsworth, CONTRACTS §3.4, at 11 (4th ed. 2004) ("[I]n forming a bilateral contract each party makes a promise: the offeror makes the promise contained in the offer, and the offeree makes a promise in return as acceptance."), with Alain Levasseur and Vincenç Feliú, The English Fox in the Louisiana Civil Law Chausse-Trappe: Civil Law Concepts in the English Language; Comparativists Beware!, 69 LA. L. REV. 715,725 (2009) Note the differing treatment of the "bilateral" or "reciprocal" contract (and not "synallagmatic or bilateral") from the unilateral contract. The reason for the difference is most likely because of the fundamental difference between the nature and legal regime of the "unilateral contract" at common law and the nature and legal regime of that contract at civil law. "Unilateral" at common law and "unilateral" at civil law had become "faux-amis!"

${ }^{14}$ For example, the Business Software Alliance, of which Apple is a member, estimated that losses as a result of software piracy in the United States exceeded \$9 Billion in 2007. See Business Software Alliance, 2007 Global Software Piracy Study (May 2008), http://global.bsa.org/idcglobalstudy2007/studies/summaryfindings globalstudy0 7.pdf. The same study shows worldwide losses as a result of piracy exceed $\$ 47$ Billion. A 2008 IDC study on the Microsoft Environment found that Microsoft Partners lose an estimated $\$ 5.50$ for every dollar spent without piracy controls. See IDC, White Paper: The Impact of Software Piracy and License Misuse on the Channel (2008), http://microsoft.com/presspass/events/wwpc/docs/softwarepiracyWP.pdf.
} 
market. In some cases, companies reportedly sell the main device at a loss with the expectation that other income will more than make up for the first sale loss. ${ }^{15}$ For example, Apple reportedly receives somewhere between $\$ 3$ and $\$ 18$ per month per iPhone from AT\&T, the exclusive cellular carrier for the Apple iPhone. ${ }^{16}$ Additionally, Apple generally receives income from the listing and purchase of applications; although users have previously hacked the iPhone in order to install applications outside of Apple's control. ${ }^{17}$ Because it is the manufacturer of the highest selling cellular phone in the cellular phone industry, ${ }^{18}$ Apple has a strong incentive to prevent consumers from jailbreaking the iPhone. In fact, Apple's presence in the smart-phone marketplace continues to grow and may threaten the overall top-five market share for cell-phones. ${ }^{19}$ Significantly, in contrast with the top five companies distributing cell phones (Motorola, Nokia, LG, Sony Ericsson and Samsung) Apple is the only company that distributes only one phone. ${ }^{20}$ If Apple is able to break into this group, it will demonstrate how dominant the iPhone is in the market. Nevertheless, it is estimated that as many as 1.7 million iPhones have never reached the AT\&T Network. ${ }^{21}$ Ensuring that

${ }^{15}$ Richard Wray, iPhone Makes Worldwide Loss, Says Report, THE GUARDIAN (Sept. 6, 2009), http://www.guardian.co.uk/business/2009/sep/06/telecomsiphone.

${ }^{16}$ See Tom Krazit, Apple Earnings Soar as iPhone Shipments Revealed, CNET NEws (July 25, 2007), http://www.news.com/Apple-earnings-soar-as-iphoneshipments-revealed/2100-1047 3-6198872.html; Tom Krazit, Piper Jaffray: AT\&T paying Apple \$18 per iPhone, per Month, CNET NEWS (Oct. 24, 2007, 1:03 PM), http://news.cnet.com/8301-13579 3-9803657-37.html (noting that Apple contracted the rights of the Apple iPhone to AT\&T).

17 Tom Krazit, Apple: iPhone Jailbreaking Violates Our, CNET NEws (Feb. 13, 2009, 11:01 AM), http://news.cnet.com/apple-iphone-jailbreaking-violatesour-copyright/.

${ }^{18}$ See Dan Frommer, Apple's iPhone The Best Selling Phone in U.S., Beats Motorola's Razr, SILICON ALLEY INSIDER (Nov. 8, 2008), http://www.alleyinsider.com/2008/11/apple-s-iphone-the-best-selling-phone-inu-s-beats-motorola-s-razr. The iPhone got off to a hot start for both cellular phones and smart phones, after one fiscal quarter, becoming the second most popular smart phone on the market. See Ryan Kim, The Tech Chronicles: Apple No. 2 in Smart Phone Sales in U.S., No. 3 World Wide, S.F. GATE (Feb. 7, 2008), http://www.sfgate.com/egibin/blogs/stgate/detail?blogid=19+entry $\mathrm{id}=24087$.

${ }^{19}$ According to revenues, Apple is the third-largest mobile phone supplier, after Nokia and Samsung. This was, as Steve Jobs pointed out, "not bad for being in the market only 15 months." Peter Cohen, Apple hits 10 Million iPhone target two months early, IOS CENTRAL (Oct. 21, 2008, 6:09PM), http://www.macworld.com/article/136284/2008/10/tenmillion.html.

${ }^{20}$ See id.

${ }^{21}$ One estimate placed the number of iPhones that remain unconnected to AT\&T's network at around 1.7 million. See Olga Kharit \& Peter Burrows, 
each of those iPhones continues to bring in profits beyond the first sale requires Apple to control the product in ways that intellectual property law will not.

99 By tying the behavioral restriction to a certain economic right, companies like Apple create incentives that reduce the number of illicit or unauthorized uses of their technology - a form of protection beyond intellectual property law. As one researcher in human behavioral norms pointed out, "since the existence of anti-piracy laws does not seem to prevent ... [software] piracy, effective measures to address the software piracy problem cannot be developed without knowing the underlying motivations and justifications for individuals to pirate." ${ }^{22}$ Likewise, it is important to assess the varying forms of incentive-based deterrents on this human behavior.

q10 This iBrief considers whether incentive-based restrictions are more successful in altering human behavior than overt legal enforcement. It argues that incentive-based restrictions can be more effective than traditional intellectual property regimes because they provide a deterrent that falls outside of a consumer's normal behavioral calculations. By incentivizing certain behavior, companies like Apple can convince people to honor the company's requested code of conduct for the product - an economic asset that Apple would protect vigorously if the law would afford an effective means of doing so.

ף11 Section II of the iBrief describes the legal obstacles faced by manufacturers such as Apple. The iBrief first considers the steps that hackers undertake to jailbreak an Apple iPhone. It also describes Apple's difficulty protecting its iPhone-related intellectual property ${ }^{23}$ with patents,

Millions of iPhones go AWOL, Bus. WK. (Jan. 28, 2008, 5:39PM)

http://www.businessweek.com/technology/content/jan2008/tc20080128 984623 htm.

${ }^{22}$ H.K. Cheng, R.R. Sims, \& H. Teegan, To Purchase or to Pirate Software: An Empirical Study, 13 J. MGMT. INFO SYs. 49, 50 (1997).

${ }^{23}$ For purposes of this iBrief, I am defining intellectual property quite broadly to include the proceeds that Apple might reap from its technology and its ability to control access to that technology, whether the law would recognize the company's ability to guard that right or not. See U.C.C. § 9-102(a)(64) (2000) (defining proceeds as anything acquired on the sale, lease, license or exchange of the property). This iBrief is not, however, taking the position that intellectual property is or necessarily should be synonymous with the set of enforceable rights the law recognizes as intellectual property. For such a more stringent view see Adam D. Moore, A Lockean Theory of Intellectual Property, 21 HAMLINE L. REV. 65, 66 (1997) (arguing that intellectual property rights be treated similarly to Anglo-American property rights). As an aside, if Apple's payments received from AT\&T were considered in Article 9 terms, they would 
copyrights, and sales warranties. Section II considers why companies like Apple are stripped of certain intellectual property rights under the first sale doctrine. It also considers the Digital Millennium Copyright Act ("DMCA") and why Apple has no remedy under it against non-compliant consumers. Finally, Section II considers the effect of the law of warranty, Article 2 of the Uniform Commercial Code, and the Magnuson-Moss Act. In doing so, the section considers certain contractual formation issues that arise in connection with the conveyance of Apple's warranty.

q12 Section III discusses the current literature on piracy and counterfeit deterrence. It highlights a model of human behavior that impacts the way humans make decisions. It also presents the thesis of this iBrief: manufacturer deterrents are more effective when they impose economic risks rather than mere legal risks. ${ }^{24}$ Section III then presents literature on deterrent impacts and suggests why Apple's warranty may be an economically effective tool to govern consumer behavior. It argues that the use of incentive-based restrictions maximizes the probability that manufacturers will succeed in protecting their property. ${ }^{25}$

q13 Section IV puts the hypothesis to the test, considering a sample pool of subjects responding to a survey regarding iPhone usage and the limited warranty's effectiveness in moderating consumer behavior. Section IV describes the methodology, results and observations yielded by this iBrief's empirical assessment of consumer behavior. Section IV also incorporates the empirical results into the Triandis behavioral model described in Section III.

be an account. See U.C.C. § 9-102 (2000) (“[A] right to payment of a monetary obligation").

${ }^{24}$ By legal risks, I mean the risk of court action and use of legal process to enforce whatever rights the manufacturer believes it possesses.

${ }^{25}$ In one way, this article argues essentially, the basic economic premise that parties efficiently allocate risk when they negotiate in arms length transactions. When parties attempt to enforce their rights through liability rules rather than property rules, they increase costs which could better have been allocated between the parties. Entitlements are protected by property rules when the only means to receive the entitlement is through arms-length bargaining. On the other hand, liability rules set aside the capacity of the individuals to negotiate effectively, thereby either confirming one party's right to the entitlement or reshuffling the deck. See Guido Calabresi \& A. Douglas Melamed, Property Rules, Liability Rules and Inalienability: One View of the Cathedral, 85 HARV. L. REV. 1089, 1092 (1972). Entitlements are protected by property rules when the only means to receive the entitlement is through arms-length bargaining. Id. On the other hand, liability rules set aside the capacity of the individuals to negotiate effectively, thereby either confirming one party's right to the entitlement or reshuffling the deck. 


\section{The Law Regulating Sellers And Manufacturers}

ף14 Understanding which laws may regulate a consumer's ability to modify (or "jailbreak") an iPhone first requires an understanding of how a user can modify the phone. ${ }^{26}$ The Apple iPhone is a hardware device with pre-loaded integrated software, called firmware, which operates the phone and other features, such as email, calendar, and music functions. Of all the ways one can modify an iPhone, the following five are the most popular: (1) replacing the AT\&T SIM (Subscriber Identity Module) card with a SIM card from another carrier, (2) downloading software to reorient (or "pwn") ${ }^{27}$ the Apple software to the universal SIM card, (3) adding installers for phone customization and unlocking the phone, (4) activating bootloader software within the program, and (5) following a process to reboot the phone. Similarly, one could accomplish the same result by simply loading software to the iPhone that causes the firmware to reorient the existing SIM card.

q15 A second, albeit more complicated, way to jailbreak an iPhone is to alter the SIM card supplied by Apple. After opening the iPhone, the hacker could attach a new wire to the phone (either by soldering or some other form of attachment), to access the phone's memory. Once accessed, the hacker could rewrite the access codes to enable any phone to access the factory installed AT\&T SIM card. The particular hacker responsible for the algorithm described above also mapped the interior of the phone to identify the location for proper hacking. This is the method then-seventeen year old George Hotz employed as the first person to unlock an iPhone. ${ }^{28}$ Each of these methods interacts with three distinct areas of law. First, the doctrines of first sale in patent and copyright law prevent Apple from enforcing

\footnotetext{
${ }^{26}$ The author in no way endorses these technologies to hack an iPhone. The information provided herein is for academic purposes only.

${ }^{27} \mathrm{PWN}$ originates from a typo for "owned" found in the video game Warcraft. The term means to dominate an opponent. See Pwned Definition, URBANDICTIONARY.COM, http://www.urbandictionary.com/define.php?term=pwned (last visited Sept. 14, 2010). In this case, the new software "dominates" the software embedded on the phone and forces it to recognize other networks. See Elaine Chow, Apple Leopard 10.5.6 Update Pwns Pwnage, Breaks Jailbreak, GizmODO (Dec. 16, 2008, 12:00 AM), http://gizmodo.com/5110996/apple-leopard-1056-updatepwns-pwnage-breaks-jailbreak.

${ }^{28}$ Brad Stone, With Software and Soldering, a Non-AT\&T iPhone, THE NEW YORK TIMES, August 25, 2007, http://www.nytimes.com/2007/08/25/technology/25iphone.html (last visited Oct $27,2010)$. Unlocking an iPhone differs from jailbreaking as unlocking allows the user to access cellular providers which otherwise would not be available; jailbreaking alters the software of the phone to allow the user to functionally alter the phone's utilities. Id.
} 
certain intellectual property rights against consumers once Apple sells the unit to the end-consumer. Patent law generally bars individuals from copying the physical device, while copyright law bars individuals from copying the device's software. After selling the device, however, Apple cannot prevent an individual consumer from jailbreaking the purchased unit.

ף16 Second, Apple may have a right to enforce certain intellectual property rights over encrypted copyrightable material under the anticircumvention provisions of the DMCA. Whether Apple may actually enforce rights under the DMCA is questionable. This issue is discussed more thoroughly below.

917 Finally, Apple may limit or disclaim a warranty on an individual unit under Article 2 of the Uniform Commercial Code with certain exceptions. One such exception would be if the terms of the warranty exclusion were not a part of the sale under Section 2-207 of the Uniform Commercial Code. These legal areas and their application are also discussed below.

\section{A. The First Sale Doctrine}

q18 The general rule is that copyright and patent owners have the right to "exploit" their intellectual property as against all other persons. As the court in Arachnid v. Merit Industries said, "[t]he act of invention itself vests an inventor with a common law or natural right to exploit the invention absent some conflicting patent rights in others." 29 Protective claims for patent holders include literal infringement, direct infringement and inducement and contribution.

I19 Despite the substantial rights that patent and copyright holders might have, those rights are limited by the first sale doctrine. An authorized first sale "exhausts the patent owner's rights as to the particular article sold." $" 30$

The patentee may surrender his monopoly in whole by the sale of his patent or in part by the sale of an article embodying the invention. His monopoly remains so long as he retains the ownership of the patented article. But sale of it exhausts the monopoly in that article and the patentee may not thereafter, by virtue of his patent, control the use or disposition of the article.... Hence, the patentee cannot control the resale price of patent articles which he has sold, either by resort to an infringement suit, or, consistently with the Sherman Act . . . by stipulating for price maintenance by his vendees ....

${ }^{29} 939$ F.2d 1574, 1578 (Fed. Cir. 1991).

${ }^{30}$ United States v. Univis Lens Co., 316 U.S. 241, 249 (1942). 
Our decisions have uniformly recognized that the purpose of the patent law is fulfilled with respect to any particular article when the patentee has received his reward for the use of his invention by the sale of the article, and that once that purpose is realized the patent law affords no basis for restraining the use and enjoyment of the thing used .... Whether the licensee sells the patented article in its completed form or sells it before completion for the purpose of enabling the buyer to finish and sell it, he has equally parted with the article, and made it the vehicle for transferring to the buyer ownership of the invention with respect to that article. To that extent, he has parted with his patent monopoly in either case, and has received in the purchase price every benefit of that monopoly which the patent law secures to him. ${ }^{31}$

q20 The first sale doctrine has also been incorporated into the law of copyright. Section 109(a) of the 1976 Copyright Act allows the owner of a copy lawfully made under the Act to "sell or otherwise dispose" of the possession of that copy. ${ }^{32}$ Like the doctrine in patent law, the first sale copyright doctrine defines the after-sale rights between the copyright owner and the owner of the copyrighted good. "The transfer of the copyright (or exclusive rights in the copyright) does not necessarily transfer ownership of any material object in which the copyright is expressed or embodied." 33

q21 The principle of exhaustion only applies to actual sales. ${ }^{34}$ They do not apply to a license or a conditional sale in which the transferee only obtains a limited right to use the work. Moreover, it is unknown whether the first sale doctrine allows someone to alter a digital copyrighted work because Section 109(a) allows for the "disposal" of the work.

${ }^{31} \mathrm{Id}$.

3217 U.S.C. $§ 109$ (2006).

${ }^{33}$ See Lothan Determan \& Aaron Xavier Fellmeth, Don't Judge a Sale by its

License: Software Transfers Under the First Sale Doctrine in the United States and the European Community, 36 U.S.F.L. REV. 1, 23 (2001); John A.

Rothchild, The Incredible Shrinking First-Sale Rule: Are Software Resale Limits Lawful?, 57 RUTGERS L. REV. 1,1 (2004).

${ }^{34}$ See Quality King Distribs., Inc. v. L'Anza Research Int'1, Inc., 523 U.S. 135, 151 (1998) ("The whole point of the first sale doctrine is that once the copyright owner places a copyrighted item in the stream of commerce by selling it, he has exhausted his exclusive statutory right to control its distribution.").

3517 U.S.C. $\$ 109$ (a). Apple could argue that consumers are actually creating a derivative work, which the first sale doctrine does not protect. The argument is that consumers make a copy and alter that copy each time they alter the actual copyrighted product. This factual occurance may be significant enough to preserve Apple's copyright claims.

On the other hand, it seems that a better rule would be to treat the copyright as subservient to the patent rights in this matter. Note that this is the approach that Article 9 takes for purposes of financing of goods, distinguishing between 
922 Under the first sale doctrine Apple cannot control the subsequent sale and use of a patented or copyrighted article after its sale. This doctrine raises an important question: Does Apple have a need to enforce certain intellectual property rights lost under the first sale doctrine? Preventing consumers from understanding the underlying technology may prevent them from using the technology in ways that adversely affect Apple's economic interests - such as its exclusivity agreement with AT\&T Wireless. Technically, the first sale doctrine limits Apple's capacity to prevent users from probing inside the phone-either physically or electronically-once users purchase the iPhone.

\section{B. The Digital Millennium Copyright Act Anti-Circumvention Provision}

q23 The DMCA, passed on October 28, 1998, is federal legislation designed to create tighter enforcement mechanisms for digital works that fall under copyright protection. ${ }^{36}$ As President Bill Clinton said, the act "is the most extensive revision of international copyright law in over 25 years." ${ }^{37}$ The DMCA's primary focus is to criminalize the circumvention of technologies that "secure digital copies of software, music and videos and literary works." 38

q24 The DMCA attempts to provide a balance between protecting use that might fall outside of the first sale doctrine and protection of copyright holders. Section 1201(a)(1)(C) of the DMCA authorizes the Librarian of Congress, upon recommendation from the Register of Copyrights, to exempt certain classes of works when "non-infringing users of copyright works are or will be adversely affected by section 1201 (a)(1)(A).",39

925 In 2006, the Librarian of Congress exempted from the DMCA "computer programs in the form of firmware that enable wireless telephone handsets to connect to a wireless telephone communication network, when circumvention is accomplished for the sole purpose of lawfully connecting

software that is commingled into a good, and software that is an intangible. See U.C.C. § 9-102 (2000).

${ }^{36}$ Digital Millennium Copyright Act, Pub. L. No. 105-304, 112 Stat. 2860

(codified in 17 U.S.C. $\S \S 512,1201-05,1301-32$ and 28 U.S.C. $\S 4001$ ).

${ }^{37}$ Statement on Signing the Digital Millennium Copyright Act, 2 PUB. PAPERS

1902 (Oct. 28, 1998), available at

http://www.presidency.ucsb.edu/ws/index.php?pid=55169.

${ }^{38}$ Jeri Clausing, Technology Bills Languish As Congress Races for Exit, N.Y. TIMES, Oct. 12, 1998, at C2, available at http://www.nytimes.com/1998/10/12/business/technology-bills-languish-ascongress-races-for-exit.html?pagewanted=all.

${ }^{39} 17$ U.S.C. $\S 1201(\mathrm{a})(1)(\mathrm{c})$. The Librarian was instructed to review the copyrights two years after the initial act, and then every three years thereafter. 
to a wireless telephone communication network." ${ }^{40}$ During the exemption process, several comments were submitted to the Librarian by consumer groups and the Register of Patents.

q26 The Wireless Alliance, advocating for the removal of restrictions against unlocking cellular telephones, advanced two principal arguments. First, they argued that the current cellular practice, which restricted unlocking cellular phones, violated a 1992 FCC ruling that prevented bundling of products and services. The ruling stated a concern that consumers were "forced to buy unwanted carrier-provided [telephones] in order to obtain necessary service." 41 The ruling allowed service providers to bundle phone sets and service only if service is also offered at a nondiscriminatory price. $^{42}$

927 The Wireless Alliance also suggested that the 1996 FCC ruling that made cellular numbers portable was analogous to unlocking cellular phones, for both imposed restrictions on consumer choice. ${ }^{43}$ Like restricted phone numbers, locked phones impose a barrier on the market preventing consumers from freely choosing their wireless carrier. ${ }^{44}$ Similarly, other comments argued that unlocking cellular phones would open the market for new technologies and more efficient economies in the cellular phone market. $^{45}$

q28 The Register of Copyrights, on the other hand, concluded that the effect on consumers' ability to make archival copies of firmware legally "appears minimal, since licensees generally define the scope of permissible archiving of software and the use of CD-ROM reduces the need to make back-up copies." 46 The Register continued, "Fair use and other copyright exceptions are not defenses to gaining unauthorized access to a copyrighted work: quoting a manuscript may be fair use; breaking into a desk drawer and stealing it is not. Circumventing access control measures was,

${ }^{40}$ Exemption to Prohibition Against Circumvention, 37 C.F.R. $§ 201.40$ (2010).

${ }^{41}$ In re Bundling of Cellular Customer Premises Equipment and Cellular Service, 7 FCC Rcd. 4028 (1992), available at 1992 WL 689944 , at*2.

${ }^{42} I d$.

${ }^{43}$ Jennifer Stisa Granick, Comment on Behalf of the Wireless Alliance Responding to Notice of Rulemaking by the Copyright Office, at 12, available at http://www.copyright.gov/1201/2006/comments/granick_wirelessalliance.pdf. ${ }^{44} \mathrm{Id}$.

${ }^{45} \mathrm{Id}$.

${ }^{46}$ U.S. COPYRIGHT OFFICE, A REPORT OF THE REGISTER OF COPYRIGHTS PURSUANT TO $\S 104$ OF THE Digital MillenNiUm CoPyright ACT XVII (2001), available at http://www.copyright.gov/reports/studies/dmca/dmca study.html. 
therefore, prohibited in the Administration's proposed implementing legislation." $" 47$

q29 On July 28, 2010, the Librarian of Congress extended the exemption under the DMCA to "software or firmware"

that enable[d] used wireless telephone handsets to connect to a wireless telecommunications network, when circumvention is initiated by the owner of the copy of the computer program solely in order to connect to a wireless telecommunications network and access to the network is authorized by the operator of the network. ${ }^{48}$

930 In addition to continuing the exemption for purposes of connecting to other cellular carriers, the ruling also exempted jailbreaking a cellular phone for the purposes of running applications. ${ }^{49}$ In doing so, the Librarian of Congress stated, "This is the fourth time that I have made such a determination. Today I have designated six classes of works. Persons who circumvent access controls in order to engage in noninfringing uses of works in these six classes will not be subject to the statutory prohibition against circumvention." 50

\$31 Thus, though the DMCA was seen by Apple as a potential source of litigation to inhibit consumers from violating Apple's terms of use, it is clear that if there is such a recourse, it will require the registrar of copyrights overturning its prior two determinations regarding cellular telephones and the DMCA; that decision is at least three years away. Indeed, Apple, has already taken to alternative means of enforcementnamely voiding consumer warranties. ${ }^{51}$

\section{The Law of Warranty and Limitation}

932 Finally, a third consideration is the extent to which Apple's limitation of warranty can be effective. Because the warranted units are "goods," the Uniform Commercial Code will apply in setting the parameters

${ }^{47} \mathrm{Id}$. at 12 .

${ }^{48}$ See Rulemaking on Exemptions from Prohibition on Circumvention of Technological Measures that Control Access to Copyrighted Works, 75 Fed. Reg. 43,825, 43,830 (Jul. 27, 2010).

${ }^{49}$ Id. at 43,829 .

${ }^{50}$ Statement of the Librarian of Congress Relating to Section 1201 Rulemaking (July 26, 2010), http://www.copyright.gov/1201/2010/Librarian-of-Congress1201-Statement.html.

${ }^{51}$ See Leander Kahney, Apple's Official Response to DMCA: It Voids Your Warranty, CulTOFMAC.COM (July 26, 2010), http://www.cultofmac.com/applesofficial-response-to-dmca-jailbreak-exemption-it-voids-your-warranty/52463. 
for warranty limitations. ${ }^{52}$ Additionally, because the iPhone is a consumer product and the warranty is written, the Magnuson-Moss Act places further restrictions on Apple's ability to limit its warranty. ${ }^{53}$ Importantly, neither body of law prevents Apple from limiting its warranty by certain covenant agreements with the consumer.

933 Article 2 of the Uniform Commercial Code governs "transactions in goods." ${ }^{, 54}$ Goods under the Uniform Commercial Code include all things "movable at the time of their identification to the contract for sale." 55 Though Article 2 does not expressly include "software" as a good, recent decisions suggest that most courts treat the licensing of software as a "transaction in goods" under Article 2-102. ${ }^{56}$ Cellular phones are certainly movable goods.

934 As a merchant under the UCC, ${ }^{57}$ Apple's products are subject to certain implied warranties - such as merchantability ${ }^{58}$ and fitness for a particular purpose ${ }^{59}$ - unless excluded or modified. ${ }^{60}$ Apple's iPhone has such an exclusion, which provides the following:

${ }^{52}$ U.C.C. § 2-102 (1999) ("Unless the context otherwise requires, this Article applies to transactions in goods.").

${ }^{53}$ Magnuson-Moss Warranty - Federal Trade Commission Improvement Act, 15 U.S.C. § 101(1)-(2) (1998) (defining consumer product as "any tangible product ... normally used for personal, family or household purposes," and defining consumer as "buyer of any consumer product").

${ }_{55}^{54}$ U.C.C. $\S 2-102(1999)$

${ }_{55}^{55}$ Id. $\S 2-105$.

${ }^{56}$ See, e.g., M.A. Mortenson Co. v. Timberline Software Corp., 998 P.2d 305, 310 (Wash. 2000) ("The parties agree in their briefing that Article 2 applies to the licensing of software, and we accept this proposition."); Olcott Int'l \& Co. v. Micro Data Base Sys., Inc., 793 N.E.2d 1063, 1071 (Ind. App. 2003). For other decisions holding that software is a good, see Micro Data Base Sys., Inc. v. Dharma Sys., Inc., 148 F.3d 649, 654 (7th Cir.1998) (applying New Hampshire law); Advent Sys. Ltd. v. Unisys Corp., 925 F.2d 670, 675-76 (3d Cir. 1991) (applying Pennsylvania law); ePresence, Inc. v. Evolve Software, Inc., 190 F.Supp.2d 159, 163 (D. Mass. 2002) (applying California law); Newcourt Fin. USA, Inc. v. FT Mortg. Cos., 161 F.Supp.2d 894, 897 (N.D. Ill. 2001) (applying Illinois law); Dahlmann v. Sulcus Hospitality Tech, Corp., 63 F. Supp. 2d 772, 775 (E.D. Mich. 1999) (applying Michigan law); Architectronics, Inc. v. Control Sys., Inc., 935 F. Supp. 425, 432 (S.D.N.Y. 1996) (applying New York law).

${ }^{57}$ U.C.C. § 2-104 (1999) ("'Merchant' means a person who deals in goods of the kind or otherwise by his occupation holds himself out as having knowledge or skill peculiar to the practices or goods involved in the transaction ....").

${ }^{58} I d . \S 2-314$.

${ }^{59} I d$. § 2-315. An implied warranty of fitness for a particular purpose is not exclusive to merchants, but applies to all sellers.

${ }^{60} I d . \S 2-316$. 
TO THE EXTENT PERMITTED BY LAW, THIS WARRANTY AND THE REMEDIES SET FORTH ABOVE ARE EXCLUSIVE AND IN LIEU OF ALL OTHER WARRANTIES, REMEDIES AND CONDITIONS, WHETHER ORAL OR WRITTEN, STATUTORY, EXPRESS OR IMPLIED. AS PERMITTED BY APPLICABLE LAW, APPLE SPECIFICALLY DISCLAIMS ANY AND ALL STATUTORY OR IMPLIED WARRANTIES, INCLUDING, WITHOUT LIMITATION, WARRANTIES OF MERCHANTABILITY AND FITNESS FOR A PARTICULAR PURPOSE AND WARRANTIES AGAINST HIDDEN OR LATENT DEFECTS. IF APPLE CANNOT LAWFULLY DISCLAIM STATUTORY OR IMPLIED WARRANTIES THEN TO THE EXTENT PERMITTED BY LAW, ALL SUCH WARRANTIES SHALL BE LIMITED IN DURATION TO THE DURATION OF THE EXPRESS WARRANTY AND TO THE REPAIR OR REPLACEMENT SERVICE AS DETERMINED BY APPLE IN ITS SOLE DISCRETION. ${ }^{61}$

935 Limitation of warranties and remedies under Articles 2-316 and 2719 are deemed to be negotiated terms of the contract between the parties, even though the consumer did not necessarily negotiate the terms. Terms such as Apple's warranty are considered "shrink wrap" terms because they are revealed when the consumer unwraps the package. Judge Easterbrook's opinion in Hill v. Gateway 2000, Inc., confirms that these shrink-wrap terms nevertheless become binding on the consumer when the consumer accepts the product from the manufacturer. ${ }^{62}$ Other courts, namely the Third Circuit in Step-Saver Data Systems Inc. v. Wyse Technology, have taken a more limited approach by ruling that such warranties do not become a part of the agreement. ${ }^{63}$ Assuming that the warranty terms would become a part of the

${ }^{61}$ Apple One (1) Year Limited Warranty for iPhone 3GS, at 2, http://images.apple.com/legal/warranty/docs/iPhone 3GS warranty.pdf.

${ }^{62} 105$ F.3d 1147 (7th Cir. 1997). Easterbrook's opinion in Hill is erroneous in claiming that the transaction at issue was not subject to UCC § 2-207 because it only involves terms by one party. Easterbrook says, "when there is only one form, § 2-207 is irrelevant." Id. Although Easterbrook's language may have been a little cavalier, it is not clear that Easterbrook is incorrect. Comment 1 specifically notes that Section 2-207 applies when only one party produces a writing. However, Comment 1 also makes clear that 2-207 operates in the context of negotiation. There seems to be less negotiation in consumer transactions - in which the consumer may or may not purchase the good-but more concern over whether the consumer accepts the terms or not. In that regard, Easterbrook's construction which allows for the consumer to return the goods within a reasonable time if he disagrees with the terms seems quite appropriate, and in fact would render 2-207 irrelevant to the transaction.

${ }^{63}$ See, e.g., Step-Saver Data Sys., Inc. v. WYSE Tech., 939 F.2d 91, 100 (3d Cir. 1991) (excluding warranty terms presented on box-top as material 
contract, Article 2-316 would allow Apple's limitation of warranty in its terms and conditions.

936 The second body of law impacting Apple's ability to limit its warranty to consumers based on compliance with certain covenants is the Magnuson-Moss Act. The Act only applies to consumer products ${ }^{64}$ and only attempts to regulate written warranties and service agreements. ${ }^{65}$ Apple's limited warranty clearly falls under the Magnuson-Moss Act as a "Limited Warranty." what its limitations and exclusions are within the terms of the warranty. ${ }^{67}$ The Magnuson-Moss Act also states that manufacturers are not required to honor warranties for repair where the damage is caused by the consumer's own use. Section 2304(c) stipulates that:

The duties under subsection (a) of this section shall not be required of the warrantor if he can show that the defect, malfunction, or failure of any warranted consumer product to conform with a written warranty, was caused by damage (not resulting from defect or malfunction) while in the possession of the consumer, or unreasonable use (including failure to provide reasonable and necessary maintenance). ${ }^{68}$

937 As a factual matter, it will be difficult at best for a consumer to demonstrate that his own tampering did not cause the damage to the iPhone or that such use was not unreasonable, thus limiting Apple's ability to refuse warranty protection.

938 The law presents Apple with some difficulties and perhaps some solutions. First, Apple loses the ability to protect its individual patent rights in the device against each individual customer that purchases an Apple iPhone. Second, it loses the ability to prevent tampering with the firmware embedded on the phone under similar first sale doctrines embodied in copyright law. Third, in theory, the DMCA affords companies like Apple a cause of action against individuals who alter their proprietary software; however, for the time being, the exceptions granted by the Librarian of Congress forestall any claim that Apple might raise under the DMCA. Finally, Apple holds certain contractual rights to limit remedies of consumers or warranties when consumers behave poorly.

alterations of the parties' agreement under 2-207). Arguably, Step-Saver's boxtop ruling would eliminate all terms not negotiated that appear additionally in shrink wrap form.

${ }_{64}^{64} 15$ U.S.C. $\S \S 2302,2303$ (2006).

${ }^{65} I d$.

${ }^{66} I d . \S 2303$.

${ }^{67} I d . \S 2302(\mathrm{a})(6)$.

${ }^{68} I d . \S 2304(\mathrm{c})$. 
I39 Can Apple's limitation of warranty be an effective deterrent to jailbreaking? This iBrief considers that question, first by considering behavioral models on consumer behavior, and then by testing the Triandis model, with empirical evidence.

\section{PIRACY AND COUNTERFEITING AlterATION}

\section{A. Human Behavioral Model on Software Piracy}

q40 Several studies have considered behavioral impacts on technology piracy. ${ }^{69}$ These studies have considered demographic identifiers of software pirates, such as gender, ${ }^{70}$ age,${ }^{71}$ occupation, ${ }^{72}$ anonymity, ${ }^{73}$ or religious and

${ }^{69}$ Piracy is clearly a political term, but appears to be accepted on both sides of the issue. For example, the software producers would use the term to refer to what is immoral or illicit activity. See B4UCopy: The Right Stuff, http://www.b4ucopy.com/rightstuff.html (last visited Oct. 17, 2010) (website created by the Business Software Alliance, aimed at college students, and defining piracy very broadly). As Lawrence Lessig points out, the "precise contours of piracy are hard to sketch," but the way piracy is used by software producers is clearly wrong. LAWRENCE LeSSIG, FreE CULTURE 18 (2002). He went on to state that,

Creative work has value; whenever I use, or take, or build upon the creative work of others, I am taking from them something of value. Whenever I take something of value from someone else, I should have their permission. The taking of something of value from someone else without permission is wrong. It is a form of piracy.

Id. As Lessig points out, the American intellectual property tradition is an instrument to preserve creative society. The current political debate (with terms like piracy) seems more interested in preserving the instrument. $I d$.

${ }^{70}$ See, e.g., S.L. Solomon \& J.A. O'Brien, The Effect of Demographic Factors on Attitudes Toward Software Piracy, 30 J. COMPUT. INFORM. SYS. 40 (1996).

${ }^{71} I d$. at 45 . Several studies have focused on the demographic of student pirates. See, e.g., Eli Cohen \& Larry Cornwell, College Students Believe Piracy is Acceptable, 1 CIS EdUCATOR F., March 1989, at 2; James R. Davis \& Ralph E. Welton, Professional Ethics: Business Students' Perceptions, 10 J. Bus. ETHICs 451 (1991); George E. Higgins \& David A. Makin, Does Social Learning Theory Condition the Effects of Low Self-Control on College Students' Software Piracy?, J. ECON. CRIME MGMT., Spring 2004, at 1, available at http://www.utica.edu/academic/institutes/ecii/publications/articles/BA3526A1F840-F4FD-3CE8AFBA74AEB151.pdf; Dave A. Hohn et al., Swashbuckling Students: An Exploratory Study of Internet Piracy, 19 SECURITY J. 75 (2006); Jin H. Im \& Pamela D. Van Epps, Software Piracy and Software Security Measures in Business Schools, 23 INFO. MGMT. 193 (1992); Stewart Kowlaski \& Harriet Kowlaski, Computer Ethics and Computer Abuse: A Study of Swedish and Canadian University Data Processing Students, 12 INFO. AGE 206 (1990); David 
ethical beliefs. ${ }^{74}$ Such studies, however, focused primarily on who is pirating software. Fewer studies have attempted to understand why people pirate software or violate intellectual property rights.

q41 In 1997, Hsning Cheng, Ronald Sims, and Hildy Teegen published To Purchase or to Pirate Software: An Empirical Study. ${ }^{75}$ Cheng, Sims, and Teegan identified nine reasons people normally pirate software: "only use it for a short time," "it is easy to copy software," "software too expensive," "newer version is coming up," "want to try out the software," "software license is too restrictive," "little chance of being caught," "most people I know copy software," and "can't afford the software." The researchers found that the most important aspects of software piracy were the economic parameters: "it appears respondents base their piracy decisions more on the economic parameters of the problem and behave as 'rational' individuals.", Despite the substantial number of reasons why people might choose to pirate software rather than purchase it, the research did not explain how individuals make these decisions. As the researchers noted, "future research is needed to understand individuals' software piracy

R. Rawlinson \& Robert A. Lupton, Cross-National Attitudes and Perceptions Concerning Software Piracy: A Comparative Study of Students from the United States and China, 83 J. EDUC. FOR Bus. 87 (2007); Robert K. Robinson \& Brian J. Reithel, The Software Piracy Dilemma in Public Administration: A Survey of University Software Policy Enforcement, 17 PUB. ADMIN. Q. 485 (1994); Ronald R. Sims et al., Toward a Profile of Student Software Piraters, 15 J. BUS. ETHICS 839 (1996); W.A. Wood, A View of Computer Ethics by Managers and Students, 32 J. COMPUTER INFO. SYS. 7 (1991).

72 See, e.g., Robinson \& Reithel, supra note 76, at 490; W.A. Wood, supra note 76, at 9; G. Steven Taylor \& J.P. Shim, A Comparative Examination of Attitudes Towards Toftware Piracy Among Business Professors and Executives, 46 HUMAN RELATIONS 419 (1993).

${ }^{73}$ See, e.g., Sameer Hinduja, Deindividuation and Internet Software Piracy, 11 CYBERPSYCHOLOGY \& BEHAVIOR 391 (2008).

${ }^{74}$ See, e.g., Im Al-Jabri \& Ali Abdul-Gader, Software Copyright Infringements: An Exploratory Study of the Effects of Individual and Peer Beliefs, 25 OMEGA InT. J. MAnAGE. SCI. 335 (1997); Debasish Banerjee et al., Modeling IT Ethics: A Study in Situational Ethics, 22 MIS QUART. 31 (1998); Susan J. Harrington, The Effect of Codes of Ethics and Personal Denial of Responsibility on Computer Abuse Judgments and Intentions, 20 MIS QUART. 257 (1996); Jeanne M. Logsdon et al., Software Piracy: Is it Related to a Level of Moral Judgment?, 13 Bus. EThics 849 (1994); Margaret A. Pierce \& John W. Henry, Computer Ethics: The Role of Personal, Informal and Formal Codes, 15 J. BUS. ETHICS 425 (1996).

${ }^{75}$ Hsning Cheng et al., To Purchase or to Pirate Software: An Empirical Study, 13 J. MANAGEMENT INFORMATION SYS. 49 (1997).

${ }^{76} \mathrm{Id}$. at 52 .

${ }^{77}$ Id. at 57 . 
decision-making process, especially when this complex process involves variables such as the pricing of software, the enforcement level of copyright law to individuals (the probability of getting caught), and individuals' moral tolerance toward software piracy." 78

q42 In 1997, Moez Limayem, Mohamed Khalifa and Wynne W. Chin, proposed a behavioral model to explain why people pirate software. The study, as stated by the researchers, was intended to "explore the link between intentions and actual behavior of software piracy." "79 The model of behavior that Limayem and others suggested was based on Triandis' Model Theory of Planned Behavior as applied to computer usage. The Triandis model considers human behavior in "terms of what they have usually done (habits), by what they think they should do (social norms) and by the consequences that they associate with a behavior (perceived consequences/ beliefs)." ${ }^{\prime 0}$ Limayem's model, depicted in Figure 1, represents the factors impacting a person's decision to pirate software.

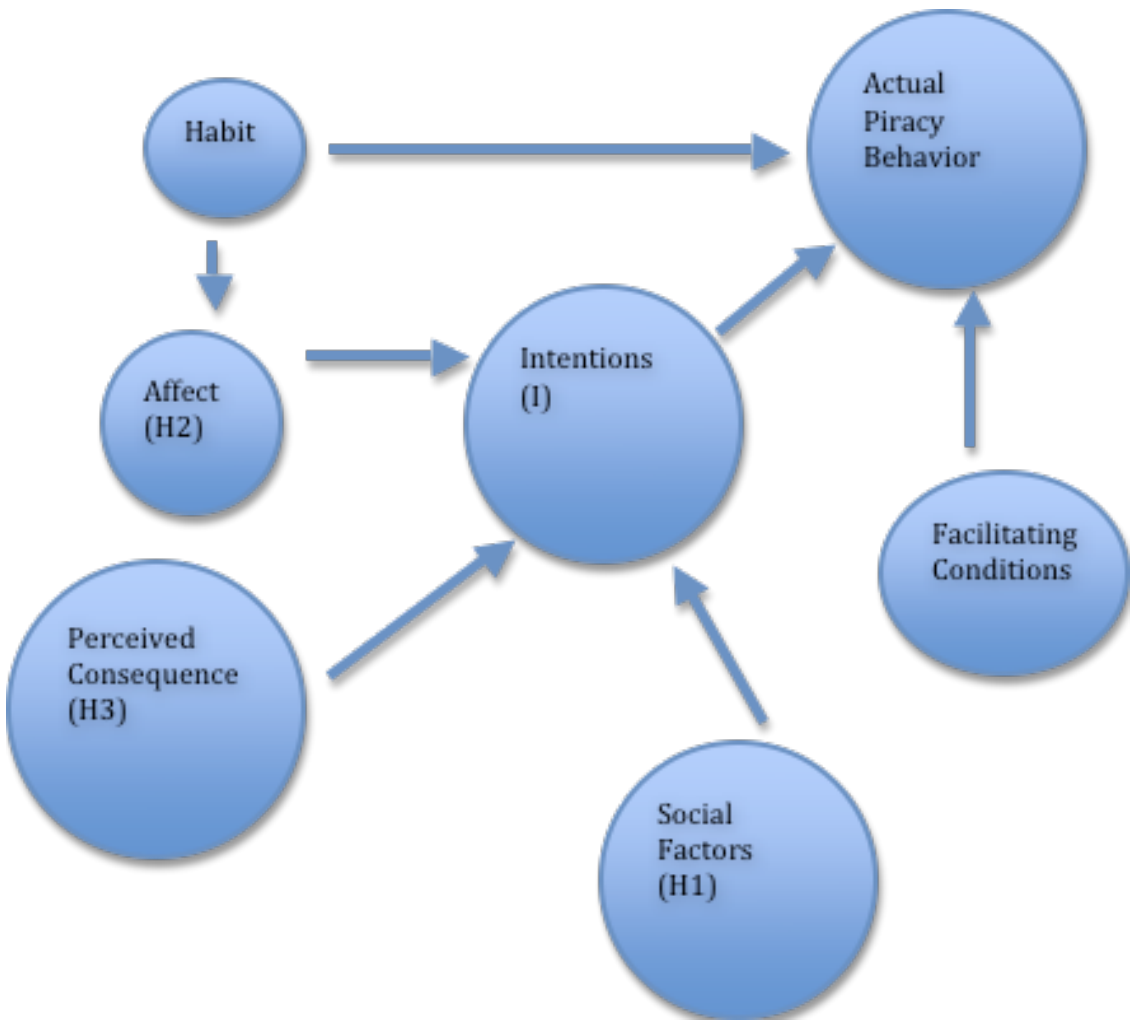

${ }^{78} I d$.

${ }^{79}$ Moez Limayem et al., Factors Motivating Software Piracy: A Longitudinal Study, 51 IEEE TRANSACTIONS ON ENGINEERING MGMT. 414, 415 (2004).

${ }^{80} I d$. at 416. 


\section{- Figure 1 - Factors of Actual Piracy Behavior}

943 The factors that primarily inform the individual's intentions are (H1) Social Factors, (H2) Affect, and (H3) Perceived Consequences. ${ }^{81}$ Social factors $(\mathrm{Hl})$ are the "norms, roles, and values at the societal level that influences the individual's intentions to pirate software." ${ }^{82}$ These factors are conveyed through social relationships, work relationships and status, family values or other means of conveying socially binding expectations upon the individual. ${ }^{83}$ Social Factors can be conveyed directly or indirectly. One example of how social factors influence software piracy is the statement "most people I know copy software."

944 Affect $(\mathrm{H} 2)$ is the internal impact of pirating software on the individual. As the researchers point out, "affect refers to an individual's feelings of joy, elation, pleasure, depression, distaste, discontentment, or hatred with respect to a particular behavior." ${ }^{\circ 5}$ Thus, if people believe that pirating software is wrong, they are unlikely to engage in pirating behavior. ${ }^{86}$ Conversely, at least one researcher found that a high tolerance for piracy, often leads to tolerant individuals pirating software themselves. ${ }^{87}$ One might further hypothesize that if one is greatly elated at the prospects of depriving a software company of its profits, even if they think pirating is wrong, then that person is more likely to pirate software at some point. Affect allows individuals to rationalize their behavior.

945 Finally, Limayem's model infers that perceived consequences/ beliefs $(H 3)$ can have either a positive or negative impact on the intention to pirate software. The researchers note "an individual's choice of behavior is based on the probability that an action will provoke a specific consequence." 88 Thus, as Cheng noted in his 1997 study, the following reasons reflect an individual's appreciation of benefits of pirating software: "software too expensive," "newer version is coming up," "want to try out

${ }^{81} I d$.

${ }^{82} I$ d.

${ }^{83} \mathrm{Id}$.

${ }^{84} \mathrm{Id}$.

${ }^{85}$ Limayem et al., supra note 84, at 417.

${ }^{86} \mathrm{See} i d$. ("In an ethical context, individuals are unlikely to intend to pirate a software if they feel that pirating software is wrong." (internal citations omitted)).

${ }^{87}$ See id. ("Logsdon, Thompson and Reid (1994) found that a high level of tolerance toward software piracy leads to this behavior. Similarly, Al-Jabri and Abdul-Gader found that individual attitudes have a significant effect on ethical intention to pirate software.").

${ }^{88} I d$. at 416. 
the software," "software license is too restrictive" and "little chance of being caught." $" 89$

I46 The Limayem model on software piracy identifies that perceived consequences can have a substantial impact on the person's intention to pirate software. The model, however, stops after identifying the perceived benefit analysis as an influence on software piracy. The model could be expanded to explain how the perceived benefit is balanced against perceived detriments. Indeed, this iBrief's thesis is that manufacturers are more likely to stem piracy behavior by making it known that the detriments of pirating software are greater than the benefits. This iBrief argues that the deterrent controls used by software and technology manufacturers are far more effective in stemming software piracy than preventive or legal measures. This is because deterrence actually provides a tangible cost to consumers when they weigh the benefits to be gained by piracy.

\section{B. An Expanded Model of Behavior and Incentives}

947 As actors weigh the perceived consequences of software piracy, their perceptions are based on a matrix of likely versus unlikely benefits and detriments. On the one hand, actors have in mind the likely benefits and detriments that may occur by pirating software: "I will likely unlock the embedded software in under two hours;" "it will likely take me more than three days to unlock the embedded software;" "I will be sued by Apple if I unlock this iPhone;" "I will not be sued by Apple, even though they have the legal right to do so, if I unlock this iPhone." Likewise, actors weigh the unlikely benefits and detriments of engaging in piracy: "I will unlikely unlock the software after hours of trying;" "I will unlikely fail at unlocking the software;" "I will unlikely be sued by Apple if I unlock this iPhone;" "I will unlikely escape civil liability if I unlock this iPhone." Thus, the matrix of benefits as likely or unlikely can be explained as depicted in figure 2 .

${ }^{89}$ Cheng, supra note 80 , at 52. 


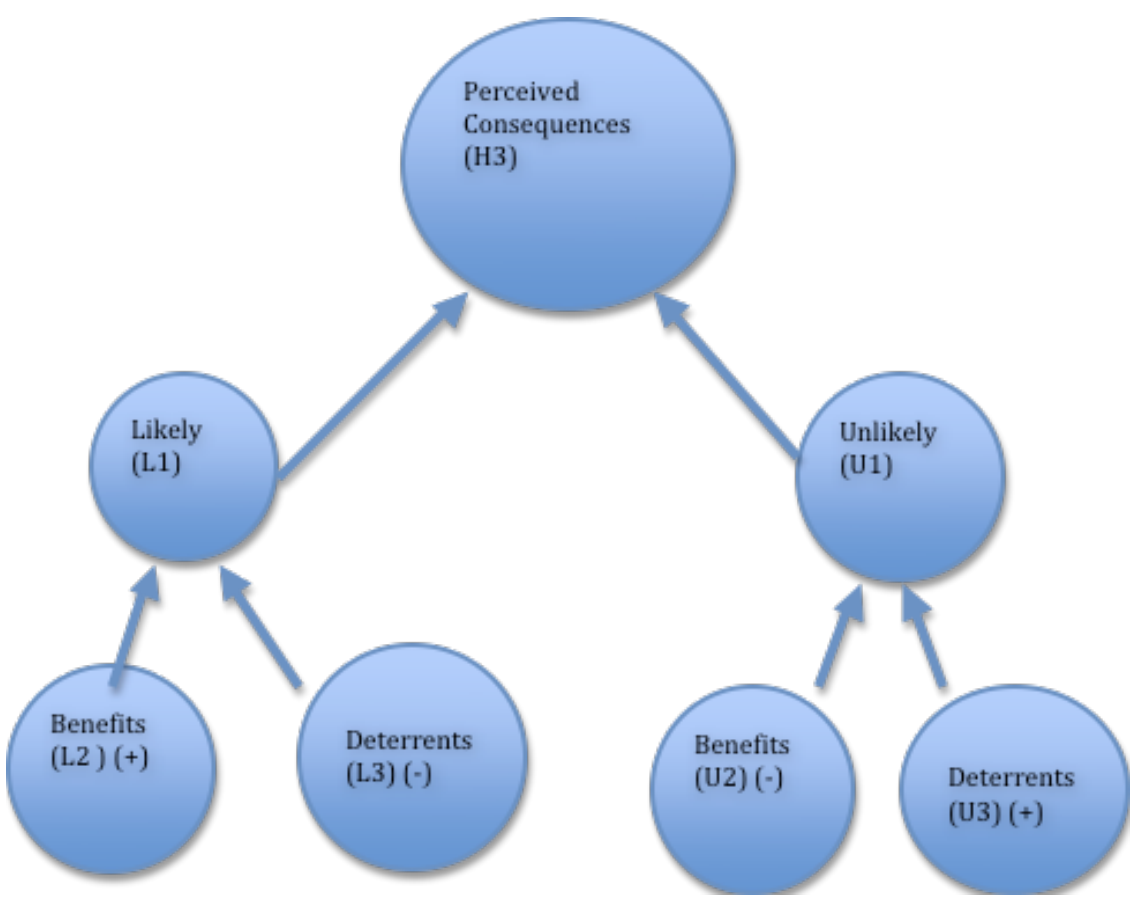

- Figure 2 - Likely/Unlikely Benefits/Deterrents

I48 Notably, the knowledge base of the individual makes a substantial difference in the outcome of the model. For example, if the actor knows that an outcome is likely to occur $(L 1)$, it is less likely that the unknown benefits/ detriments can have a negative or positive impact on the actor's decision to commit software piracy. However, where the knowledge base is less than certain $(U 1)$, then the likelihood that unknown benefits or detriments can have a negative or positive impact is greater. In short, if the actor is aware of the benefits and consequences of pirating software, then those factors have a more substantial impact on the actor's decision than if both qualities are unknown.

q49 Also, the benefits/deterrents analyses have inverse qualities depending on whether they are known or unknown. So, under L1, the benefits that are likely to be received from pirated software have a positive impact, while the deterrents have a negative impact. This can be described by a simple mathematical equation: where $L 2$ is greater than $L 3$, the likely known benefits will weigh more favorably towards piracy than where $L 3$ is greater than L2. Similarly, where the unlikely benefits (U2) are less than unlikely deterrents (U3), the likelihood of piracy also goes up. Where both the unlikely deterrents (U3) are low or the likely deterrents are high (L3), the equation shifts against piracy. 
950 This effect could be expressed mathematically. First, the model reflects the simple economic postulate that people will engage in behavior they deem to be more beneficial than detrimental. Thus, the perceived consequences $(P C)$ will favor piracy where the sum of the benefit $(B)$ and the impact of the detriment $(D)$ are greater than zero.

$$
P C=B-D
$$

951 Second, the model recognizes that both the benefits and detriments carry their own magnitude. Being sued or having a criminal sanction levied against an individual may be more of a detriment than losing rights one did not know or care about in the first place. Thus, after incorporating a magnitude of benefit $(M)$ and a magnitude of detriment $(N)$, the formula now is:

$$
P C=(M B)-(N D)
$$

952 Third, the model includes an issue of probability. That is, consumers may very well deem the risk of being sued to be a strong deterrent, but consider its probability relatively weak. Thus, incorporating a probability factor for benefits $(X)$ and a probability factor for detriments $(F)$, the formula now is:

$$
P C=(X(M B))-(F((N D))
$$

953 Finally, the model recognizes the possibility of multiple benefits and multiple detriments. Thus, our expanded formula is:

$$
P C=\left(\left(X_{1}\left(M_{1} B_{1}\right)\right)+\left(X_{2}\left(M_{2} B_{2}\right)\right)-\left(F_{1}\left(N_{l} D_{l}\right)+\left(F_{2}\left(N_{2} D_{2}\right)\right)\right.\right.
$$

954 The likely and unlikely benefits of actors in software piracy can be managed by software manufacturers that impose various controls. Deterrent actions by software manufacturers can take on two qualities: preventative and deterrent. Preventative actions force actors to expend and deplete resources in pursuit of a goal. ${ }^{90}$ Typically, preventive controls include actions such as using copy-protection, encrypting, providing customer support to only registered users, and providing documentation such as user manuals that are expensive or difficult to reproduce. ${ }^{91}$

q55 On the other hand, deterrent controls, do not directly increase costs, but impose costs on actors. ${ }^{92}$ Deterrent controls can be legal, economic, or

${ }^{90}$ Ram D. Gopal \& Lawrence Sanders, Preventive and Deterrent Controls for Software Piracy, 13 J. MGMT. INFO. SYS. 29, 30 (1997).

${ }^{91}$ See id. ("Preventive controls use technology to increase the costs of engaging in acts of piracy.").

${ }_{92}$ See id. at 31 ("Deterrent controls, in contrast to preventive controls, do not directly increase the cost of pirating software. Deterrence is achieved if an individual avoids criminal behavior out of the perceived threat or fear of the inherent elements of sanctions."). 
both. In order for deterrent controls to be effective, actors must be aware that they may be subject to certain costs for engaging in certain behavior. Thus, software companies often engage in public education programs to inform consumers of the legal consequences that software piracy brings.

956 According to Gopal and Sanders, software manufacturers' use of deterrent controls can be as effective as preventive controls and can result in greater profits because it costs far less to implement. ${ }^{93}$ Gopal and Sanders focused their model description on the impact of potential civil liability on software piracy. ${ }^{94}$ This model argues that consumers can regard economic loss as a greater incentive against software piracy than the threat of civil liability. ${ }^{95}$

957 More importantly, this iBrief argues that software producers should seek to expand the knowledge base of actors as to the loss of warranties, and that such knowledge could have an even greater impact on the preservation of intellectual property rights than expanding the actors' knowledge base as to legal consequences. As explained in Part III, this iBrief describes how known incentives can serve as a successful deterrent against piracy.

\section{EMPIRICAL ANALYSIS OF INCENTIVE-BASED ALTERATION THEORY}

958 To test the behavioral model described in Part II, two survey pools were asked questions regarding decision making and modifying an Apple iPhone. This part lays out (A) the survey pools; (B) the survey methodology; (C) the survey results; and (D) offers certain conclusions based on the survey's findings.

\section{A. The Survey Pool}

959 The survey pool attempted to sample from pools of individuals likely familiar with the Apple iPhone. Two online surveys were sent out utilizing Facebook, an online social website. The first survey was directed to a general public audience, while the second survey was directed to college and graduate school students.

960 Unintentionally, the resulting survey pool largely mirrors the target demographic that Apple used in marketing the iPhone. For example, the majority of non-student responders fell in the 25-34 age range (59.3\%). ${ }^{96}$ The next two highest sets of responders identified themselves in the 35-44

\footnotetext{
${ }^{93}$ Gopal \& Sanders, supra note 91 , at 30.

${ }^{94} I d$. at 30 .

${ }^{95} \mathrm{Id}$. at 30 .

${ }^{96}$ See infra App. 1-17.
} 
age range (11.1\%) and the 45-54 age range (18.5\%). ${ }^{97}$ The likely age demographic for the Apple iPhone is $18-35$ years old. ${ }^{98}$

961 Another important similarity between the survey pool and Apple's purchasing demographic is the educational background/ occupation/ household income. In the survey pool, a vast majority completed at least one college degree $(85.7 \%){ }^{99}$ A majority of those surveyed had completed a degree beyond a bachelor degree (60.3\%). ${ }^{100}$ This reflected itself as well in the listed occupations: law was the highest field of expertise $(29.1 \%)$, followed by other (29.1\%), philosophy/ religion (16.4\%), technology and engineering (14.6\%), Medicine (5.5\%) and Sales (1.8\%). ${ }^{101}$ The highest percentage of annual household income fell between $\$ 100,000$ - $\$ 149,999$ $(19.2 \%)$, followed by $\$ 75,000-99,999(17.3 \%), \$ 50,000-\$ 74,999$ $(17.3 \%) ; \$ 35,000-\$ 49,999(15.4 \%)$, and $\$ 25,000-\$ 34,999(11.5 \%){ }^{102}$ Only $3.8 \%$ of the responders fell below $\$ 25,000$, and $15.4 \%$ of responders made more than $\$ 150,000$. ${ }^{103}$ Similarly, the Apple iPhone is most often purchased by those that make more than $\$ 60,000$, and it has been attractive as an alternative to the Blackberry as a PDA device. ${ }^{104}$

962 Finally, a separate survey was distributed that specifically targeted students. Demographic information was not taken regarding household income, education, or age because of the possibility of skewing other

${ }^{97} \mathrm{Id}$

${ }^{98}$ See Bill Tancer, A Closer Look at iPhone Lust, TIME.COM (July 11, 2007), http://www.time.com/time/business/article/0,8599,1642324,00.html?xid=feedcnn-topics ("Based on the demographics of visitors to the official iPhone site, we know that potential buyers skew slightly male (51.8\%), are likely to be between the age of 18-24 (31\%) and fit into an affluent urban demographic (11.6\%)"); Aidan Malley, Apple, AT\&T Neophytes to Define iPhone AudienceReport, APPLE INSIDER (June 6, 2007, 8:00PM), http://www.appleinsider.com/articles/07/06/06/apple att neophytes to define $\mathrm{i}$ phone audience report.html ("Less shocking were the cultural and gender demographics of the interested subjects. The majority fit the pattern of the young, successful male. According to Solutions Research Group, the average iPhone customer is a 31-year-old man with a college degree and an income of $\$ 75,600$ per year - a salary 26 percent higher than the American average. Almost half (43 percent) of all likely buyers lived in technically adept states such as California and New York, but only 28 percent were female. Younger buyers dominated, with 63 percent aged 34 or younger.").

${ }^{99}$ See infra App. 1-13; see also Tancer, supra note 103; Malley, supra note 103.

${ }^{100}$ See infra App. 1-13.

${ }^{101}$ See infra App. 1-14.

${ }_{102}$ See infra App. 1-18.

${ }^{103} I d$.

${ }^{104}$ See Malley, supra note 103; see also Michael Foschetti, Blackberry vs.

iPhone: A Rivalry to Benefit All, MOBILE MARKETER (July 31, 2008), http://www.mobilemarketer.com/cms/opinion/columns/1432.html. 
results. The student survey was identical to the Facebook survey with the exception of demographic questions. The student survey is an important aspect of the empirical analysis for two reasons: First, college and graduate school students are clearly target demographics for Apple in marketing its iPhone product. ${ }^{105}$ Second, many studies have targeted students in the area of technological piracy because of the perception that students tend to pirate technology more regularly than the general public. ${ }^{106}$ By creating a separate survey pool of students, comparisons with prior studies can be made to determine whether prior findings are an accurate reflection of students' use of the Apple iPhone. The survey was distributed primarily to law students, though approximately $8 \%$ of the students surveyed were non-law students. ${ }^{107}$

963 As with any survey pool, the survey may not inform us of certain reflections and biases. For example, the survey did not ask if a respondent's iPhone was provided by his or her employer. Similarly, the survey did not distinguish between geographic biases. Finally, the survey is slightly tilted towards the educated and the upper-middle class. I have suggested that the survey base is supportable because of the similar demographic that Apple targets in selling the same device; nevertheless, it is important to recognize that there may be different results with a broader or more diverse survey pool.

${ }^{105}$ Indeed, one report placed a substantial consuming demographic between 18 and 24 years of age (31\%). Tancer, supra note 103.

${ }^{106}$. Several studies have focused on the demographic of student piraters. See e.g., David R. Rawlinson et al., Cross-National Attitudes and Perceptions Concerning Software Piracy: A Comparative Study of Students from the United States and China, $2007 \mathrm{~J}$. EDUC. For BUS. 87 (2007); D.A. Hohn \& A.L. Wilson, Swashbuckling Students: An Exploratory Study of Internet Piracy, 19 SeCURITY J. 75 (2006); G.E Higgins, \& D.A. Makin, Does Social learning theory condition the effects of low self-control on College Students' software piracy?, 2 J. ECON. CRIME MANAGEMENT 1 (2004); R.K. Robinson and B.J. Reithel, The Software Piracy Dilema R.R. Sims, H.K. Cheng, and H. Teegan, Toward a Profile of student software piraters, 15 J. Bus. ETHICs 839 (1996);W.A. Wood, A View of Computer Ethics by Managers and Students, 32 J. COMPUT. INFORM. SYs. 7 (1991); J.H. Im and P.D. Van Epps, Software Piracy and Software Security Measures in Business Schools, 18 InForm. MANAGE. 193 (1992); S. Kowlaski and H. Kowlaski, Computer Ethics and Computer Abuse: A Study of Swedish and Canadian University Data Processing Students, 12 InForM. Age 206 (1990); J.R. Davis and R.E. Welton, Professional Ethics: Business Students' Perceptions, 10 J. Bus. Ethics 451 (1991); E. Cohen \& L. Cornwell, College Students Believe Piracy is Acceptable, 1989 CIS Educator Forum 2 (1989).

${ }^{107}$ See infra App. 1-14. While the survey was distributed primarily to law students (92\%), the Facebook pool was given the option of completing either the Facebook survey or the student survey, depending on whether they considered themselves a student or not. Thus, $3.4 \%$ of the students identified themselves as studying philosophy, $2.3 \%$ identified themselves as studying engineering, and $1.1 \%$ identified themselves as studying business and computer science. 


\section{B. The Survey Methodology}

964 The two survey pools accessed and interacted with the survey in the same manner. Separate surveys were created using a third-party website and links were provided to participants, who at their leisure accessed the survey and completed it. The surveys were anonymously administered, with the exception of certain demographic information collected, as described in sub-part A above.

965 The survey asked twelve substantive questions of the participants. Several of the questions were yes/no type questions. The rest of the survey questions asked the participants to identify on a scale of nine choices (with an equal modifier) which result most likely describes them. The survey did not ask respondents to fill in responses outside of the prescribed format.

\section{Observations Based on Gathered Data}

966 The data gathered allows us to draw several observations. The data presented in Questions 3, 4, 5, and 8 reflect the participants' willingness to jailbreak the iPhone under certain conditions. Average scores for these questions closer to 1 show that the participants are less likely to engage jailbreak an iPhone. Average scores closer to 9 reflect a higher tendency to jailbreak an iPhone. 5 is the median response. Questions 4, 5, and 8 suggest the magnitude that participants consider civil liability, warranty and "better warranty" as deterrents. The data presented in Questions 6 and 7 ask the participants to weigh the conditions of liability and loss of warranty against each other for both probability and impact. Average answers between 6 and 9 indicate that the participant deems loss of warranty to be a more compelling answer, whereas an average answer between 1 and 4 indicates that the participants deemed civil liability to be more compelling. An answer of 5 reflects that the participant believed that both deterrents were equally suited to the answer.

Observation \# 1 - Introducing known sanctions will reduce the preference for pirating the iPhone.

967 Question 3 asked respondents "if you were aware of the technical means of altering the iPhone so that it was compatible with any Cellular Phone Service Provider (and assuming that your current Cellular service provider was not compatible with the iPhone), how likely would you alter the phone for its compatibility?" On a scale of 1-9, with 9 being "I would definitely alter the iPhone," and 1 being "I would never alter the iPhone," the average response was 5.47. More than half of the total respondents indicated either a preference for jailbreaking the iPhone or were neutral. ${ }^{108}$

${ }^{108}$ See infra App. 1-3. A preference for altering the iPhone is indicated by selecting a $9,8,7$, or 6 on the survey. 


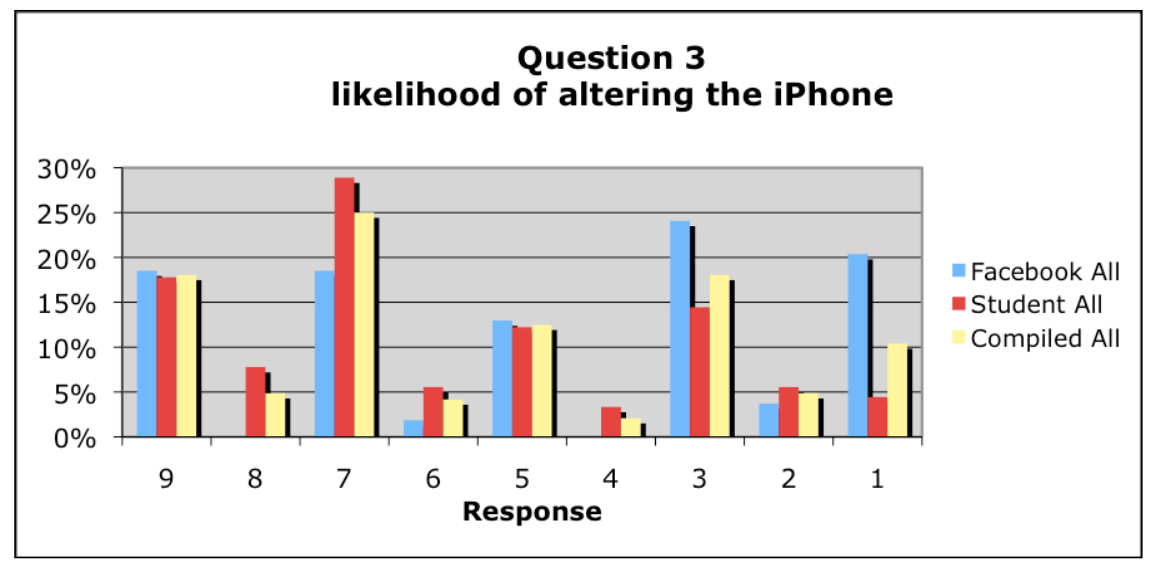

968 Question 4 asked the participants how likely they would be to jailbreak the iPhone if they were aware that jailbreaking the iPhone would expose them to monetary liability. Taking the results from Question 3, and filtering out those that indicated a preference for not jailbreaking the iPhone (those that responded with a 4 or lower), the results suggest that knowledge of civil liability would impact consumers' decisions to jailbreak the iPhone. Of the participants that had a preference for jailbreaking the iPhone (an average of 7.20), when asked whether they would be deterred if faced with civil liability, the average response dropped to $4.25{ }^{109}$ Of those responses, over half indicated a preference against jailbreaking the iPhone by responding with a $4,3,2$, or $1.17 .89 \%$ indicated that they definitely would not jailbreak the iPhone. ${ }^{110}$

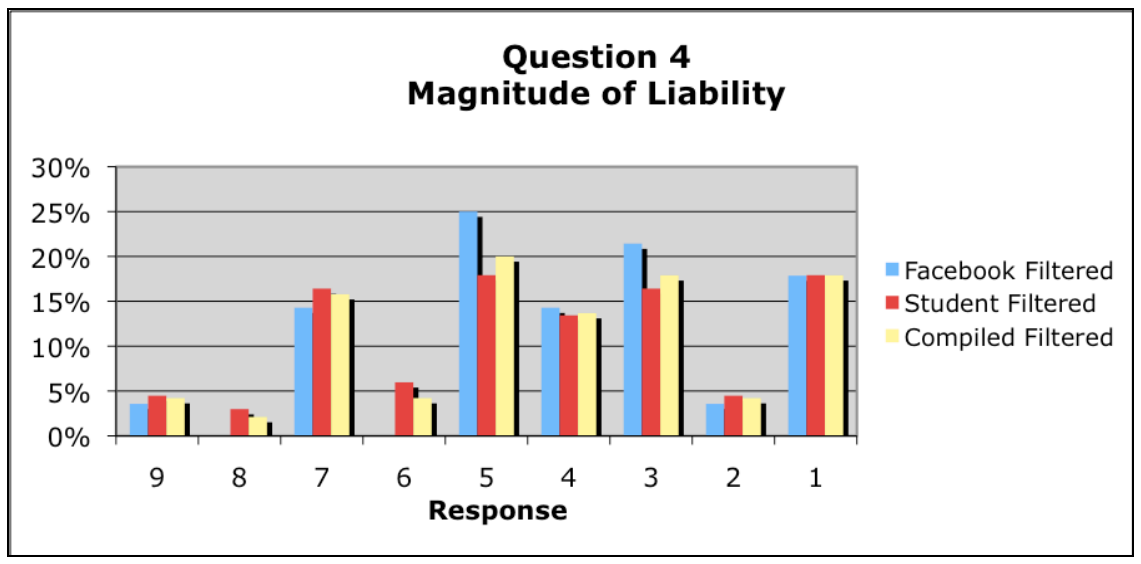

969 Similarly, the same group of filtered respondents that before indicated a preference for jailbreaking the iPhone, in Question 5 suggested

${ }^{109}$ See infra App. 1-4.
${ }^{110}$ See id. 
that the loss of warranty might jailbreak their decision, but not as significantly as the threat of civil liability. On a scale of 1 to 9,9 being "I would definitely alter the iPhone," and 1 being "I would never alter the iPhone," the average response was 5.01. ${ }^{111}$ Recall that the average response of these participants in Question 3 (when asked whether they would jailbreak an iPhone with no known deterrents imposed) was 7.19.

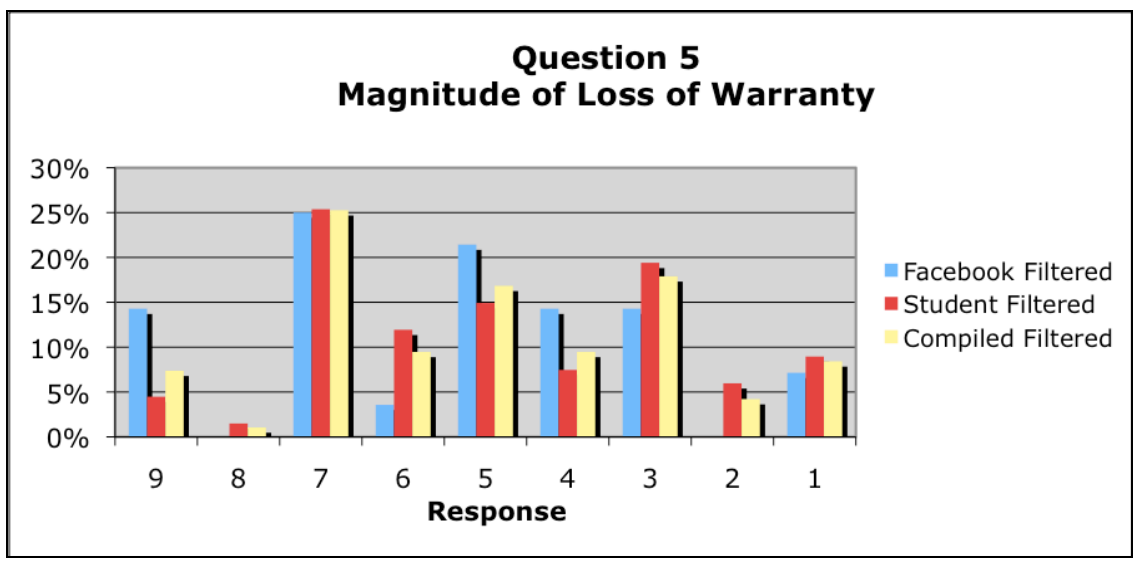

970 Questions 4 and 5 indicate how costly (compared to altering an iPhone) participants deemed either civil liability or loss of warranty. Putting this question in terms of the model and equation presented in Part II supra, both questions represent the magnitude of both deterrents $(\mathrm{N})$. Factoring the responses into a magnitude number, we can begin to assess the likelihood of jailbreaking an iPhone when faced with these sanctions. On a scale of $0-8$, the civil liability magnitude is a $4.75 .{ }^{112}$ The magnitude for losing a warranty, on the other hand, is factored at 3.99. On the perceived consequences calculation, the magnitude multiplies by the deterrent impact, multiplied by the probability of occurrence. ${ }^{113}$

${ }_{111}^{111}$ See infra App. 1-5.

${ }^{112}$ The numbers were factored to a scale of $0-8$, with 8 being the highest probability of deterrence and 0 being the least possibility of deterrence. Using the numbers as reported would result in a skewed factor, since some indicated a possibility that they "definitely would not alter the iPhone." Those responses on the survey were noted as a "1." To remove their effect from the magnitude, the numbers were adjusted so that the responses of "I would definitely not alter an iPhone -1 " now are factored at 8 . The rest of the responses are factored similarly, 2's become 7's, 3's become 6's, etc. See infra App. 3. This procedure was replicated to determine the magnitude for civil liability (Question 4), loss of warranty (Question 5) and loss of better warranty (Question 8).

${ }^{113}$ Perceived Consequences Calculation: $P C=(X(M B))-(F(N D))$; see supra $\mathrm{p}$. 25. 
Observation \#2 - Participants believe that they are more likely to lose their warranty coverage for jailbreaking an iPhone than face civil liability.

971 Question 6 asks respondents: "On a sliding scale, do you believe that you are more likely to lose warranty coverage from Apple or be sued by Apple for altering an Apple iPhone." Considering only the respondents that indicated a preference for jailbreaking the iPhone in Question 3, the overwhelming response was that they would more likely lose warranty coverage than face civil liability. On a scale of $1-9,9$ being "I will definitely lose the warranty and not be sued," and 1 being "I will definitely be sued, but not lose the warranty," the average response was a $7.35 .{ }^{114}$

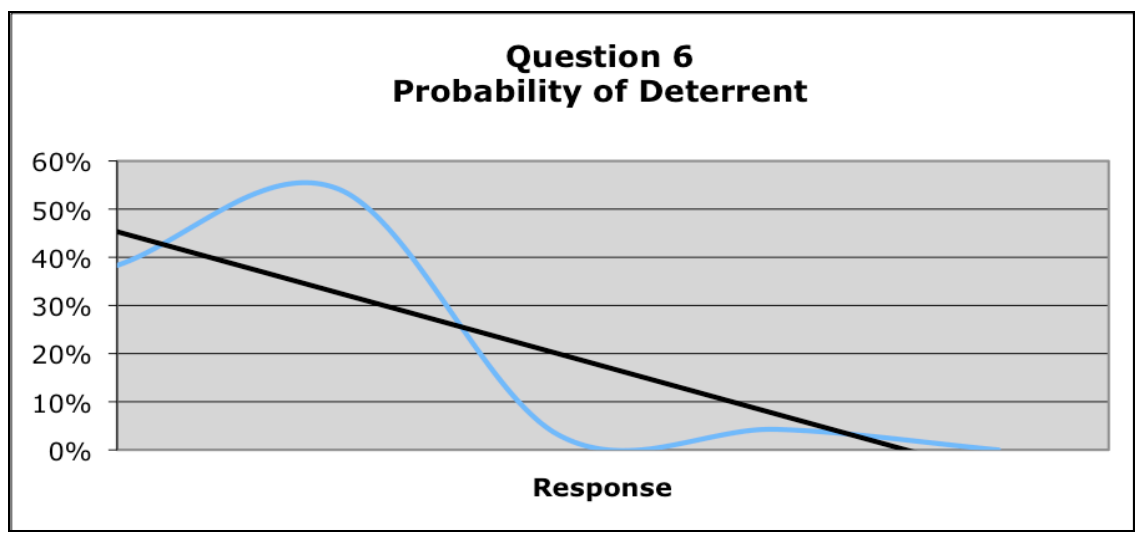

972 Similarly, Question 9 asked respondents: "Are you aware that altering the technical configurations that restrict an Apple iPhone to use on the AT\&T Wireless Network can result in a lawsuit by Apple for improper circumvention of its copyright protection?" $35.8 \%$ responded yes, while $60.8 \%$ responded no. ${ }^{15}$ Question 9 poses the possibility of a lawsuit, indicating that $35.8 \%$ believe that a lawsuit would be possible, while $60.8 \%$ don't believe that Apple could bring a lawsuit under existing laws. Interestingly, Apple has hinted at various times that it would pursue a legal claim against those that jailbreak their iPhone to subvert the exclusive arrangement Apple has with AT\&T. ${ }^{116}$ Nevertheless, either these threats went unnoticed by the survey pool, or people do not deem them to be credible.

${ }^{114}$ See infra App. 1-6.

${ }^{115}$ See infra App. 1-9.

${ }^{116}$ See Cody McCloy, Could Jailbreaking Your iPhone Land You in Jail?, CNN

SCITECH BLOG (Feb. 18, 2009, 9:56 AM),

http://scitech.blogs.cnn.com/2009/02/18/could-jailbreaking-your-iphone-landyou -in-jail/. 


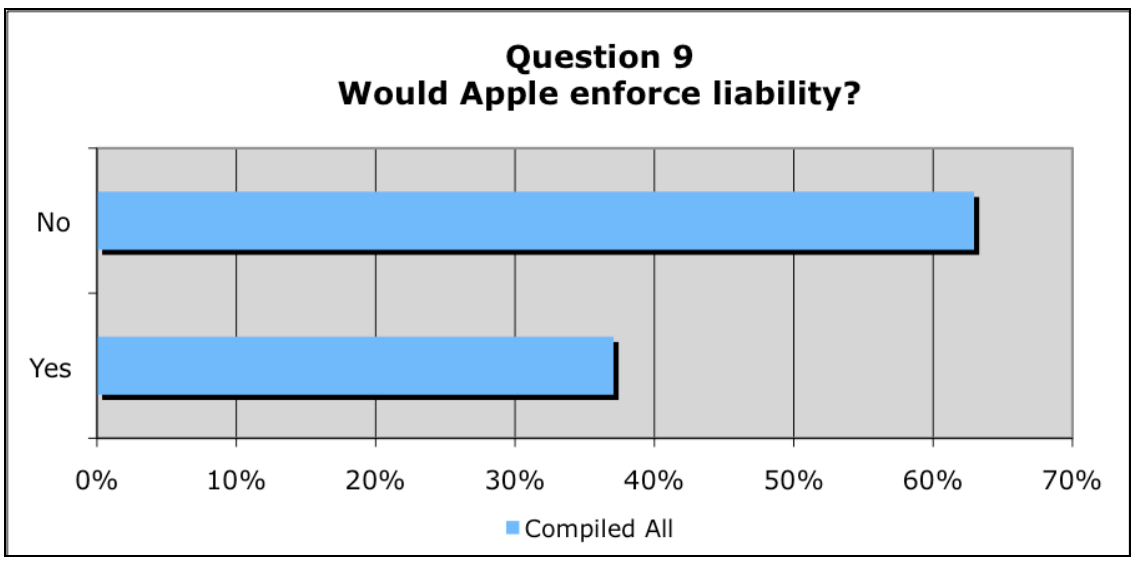

973 The effect of this finding is to somewhat diminish the impact that monetary liability has on participants' decisions to pirate technology. Notably, it has the inverse impact on warranty liability. To demonstrate, consider the previous mathematical expression of the behavioral model in Part II. ${ }^{117}$ Utilizing the answers provided in Question 6, a factor of probability can be created for the likelihood of losing a warranty and the imposition of civil liability. Adjusting the factor to a range of $0-8$, where 0 represents no possibility of the deterrent occurring, and 8 representing the maximum possibility of the deterrent occurring, we get a probability factor for loss of warranty at 6.35 and a probability factor for civil liability at only 1.65 . $^{118}$ When accounting for the probability of deterrents, we see a dramatic shift in the deterrent impact of warranties and liability.

\section{Perceived Consequences Calculation: Magnitude and Probability}

Liability: $P C=X(M B)-7.84 D^{119}$

Loss of Warranty: $P C=X(M)(B)-25.33 D^{120}$

${ }^{117}$ Perceived Consequences Calculation: $P C=(X(M B))-(F(N D))$.

${ }^{118}$ As with the magnitude factor, the numbers in Question 6 were converted to a range of $0-8$. An 8 indicates that the sanction is most likely, while 0 indicates that the participant deemed no possibility of the sanction occurring. As to the factor for probability of the loss of warranty, the numbers correspond directly: 9's become 8's, 7's become 6's, 5's become 4's etc.

The factor for civil liability, however, had to be inverted and then adjusted. Thus, the 9's in Question 6 become 0's, 8's become 1's, and 7's become 2's, while 1's become 8's, 2's become 7's etc.

${ }^{119}$ (N) Magnitude for Liability -4.75 ; (f) Probability of liability -1.65 .

${ }^{120}$ (N) Magnitude for Liability - 3.99; (f) Probability of loss of warranty -6.35 . 
974 Notice that the loss of warranty is three times more effective as a deterrent than the value of liability. These numbers in themselves are persuasive. One conclusion that these numbers may suggest is not necessarily the power that losing a warranty may have over consumers (which is questionable), but rather how impotent veiled threats of consumer litigation fail to sway consumer decision-making. To put it concretely, even though the percentage of people that would be deterred by monetary liability was higher, most people did not deem that sanction to be realistic. Moreover, a substantial majority thought that they were much more likely to lose their warranty over being exposed to monetary liability.

975 Notably, this does not take into account the impact of the two deterrents. In fact, the participants in the survey agreed that civil liability, if probable, would be more of a deterrent than losing a warranty. Question 7 asked respondents "[o]n a sliding scale of 1-9, which sanction is a greater deterrent to altering an Apple iPhone: losing the manufacturers Limited Warranty or possible civil liability?" Considering only the respondents that indicated a preference for jailbreaking the iPhone in Question 3, 61.70\% of the respondents indicated that being sued is more of a deterrent that losing a warranty, ${ }^{121}$ and only $28.73 \%$ of the respondents suggested that losing a warranty was a greater deterrent than the imposition of civil liability. ${ }^{122}$ $9.57 \%$ of the respondents indicated that both were equal deterrents. ${ }^{123}$ In other words, the factor of impact for civil liability is 4.84 , while the factor of impact for loss of warranty is 3.16. ${ }^{124}$ When calculating these impact figures, civil liability was not considered so powerful as to overwhelm the probability that companies like Apple will not seek a civil liability remedy for jailbreaking an iPhone.

\section{Perceived Consequences Calculation: Magnitude, Impact and Probability of Deterrents}

$$
\text { Liability: } P C=X(M B)-37.93^{125}
$$

\footnotetext{
${ }^{121}$ Compiled responses of those that answered with a 4, 3, 2, or 1 . See infra App. 1-7.

${ }^{122}$ Compiled responses of those that answered 9, 8, 7, or 6. See infra App. 1-7.

${ }^{123}$ Infra App. 1-7.

${ }^{124}$ The factor for the impact was created in the same way that the probability factor was created in Question 6. Using a scale of $0-8$, as to the loss of warranty, the 9's are factored as an 8, 7's a 6, etc. As to imposition of civil liability, the factors were inverted and then applied: the 1's become 8's, the 2's become 7's, etc.

${ }^{125}$ (N) Magnitude for Liability -4.75 ; (f) Probability of liability - 1.65; (d) impact of deterrent $=4.84$.
} 


\section{Loss of Warranty: $P C=X(M)(B)-80.08126$}

976 As depicted on the behavioral model in Part II, the results turn on whether individuals are more likely to consider the potential legal liability as a likely or unlikely deterrent. When posited against civil liability, participants consider loss of a warranty a more likely deterrent. In fact, every participant indicated at least a possibility of losing the warranty, even with $20.42 \%$ of all persons surveyed indicating that they did not believe that there was any possibility that they would be sued. ${ }^{127}$

Observation \# 3 - The warranty provided by Apple could deter more individuals if individuals knew that the loss of the warranty would be a significant loss.

977 Question 8 asked respondents: "If you deemed the quality of warranty coverage to be really good, would that make you more or less likely to alter the iPhone at the risk of losing the warranty?" Considering only the respondents that indicated a preference for jailbreaking the iPhone in Question 3, 55.31\% of the respondents selected a 4, 3, 2, or 1 indicating a preference to not jailbreak the iPhone in the face of better warranties. ${ }^{128}$ Only $20.21 \%$ indicated a preference for jailbreaking the iPhone, despite the better warranty, ${ }^{129}$ while $24.47 \%$ indicated that they are still more likely as not to jailbreak the iPhone. ${ }^{130}$

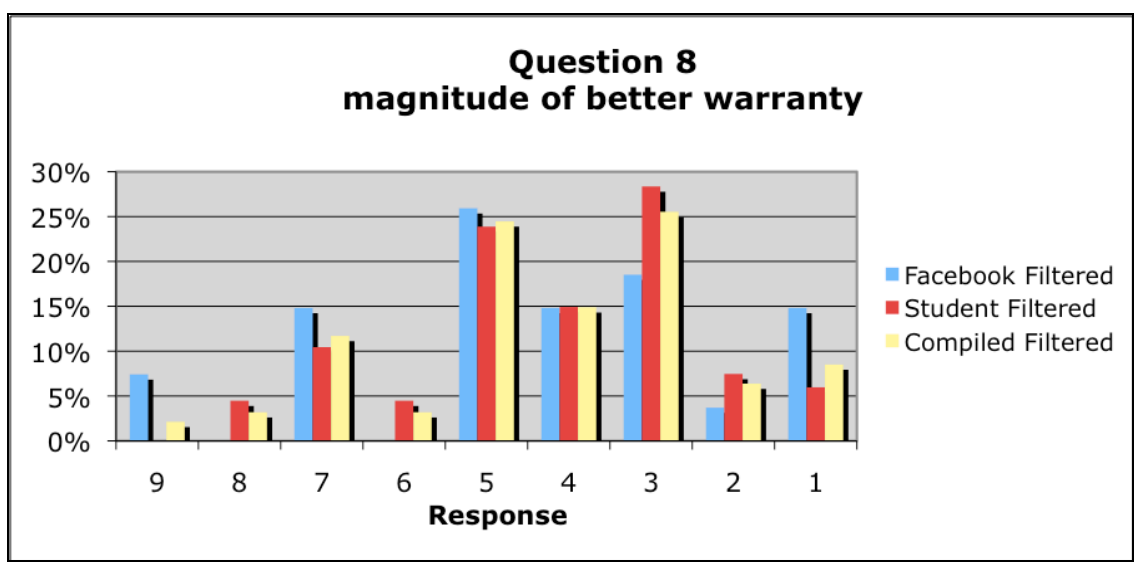

${ }^{126}$ (N) Magnitude for Liability - 3.99; (f) Probability of loss of warranty - 6.35;

(d) impact of deterrent $=3.16$.

${ }^{127}$ See infra App. 1-6.

${ }^{128}$ See infra App.1-8.

${ }^{129}$ Those indicating a preference for altering the iPhone selected a 9, 8, 7, or 6 . See infra App. 1-8.

${ }^{130} I d$. 
978 When compared with the responses in Question 5, whether the loss of the warranty would alter their behavior, consumers were more likely to not engage in piracy when the warranty was better. Indeed, the trend lines indicate a significant movement towards a preference to not jailbreak the iPhone. The overall average for Question 8 was 4.26, whereas the average response for Question 5 was 5.01 (for which a response closer to zero indicates a greater likelihood to not engage in technology piracy). Similarly, when creating a magnitude factor for "better warranty" (4.74) the warranty magnitude increased to nearly equal the average impact for civil liability, which in Question 4 was 4.75. Although the answers against civil liability were more definitive (a higher number of 1's), the overall imprint of the sample pool indicates that on average, nearly the same effect can be accomplished by enticing consumer behavior with certain improvements. Thus, the increase of loss of warranty as a deterrent is even greater if the warranty is deemed to be of high value to the consumer.

\section{Perceived Consequences Calculation: Magnitude, Impact and Probability of Deterrents}

Liability: $P C=X(M B)-37.93^{131}$

Loss of Warranty: $P C=X(M)(B)-80.08^{132}$

Loss of Better Warranty: $P C=X(M)(B)-95.31^{133}$

Observation \# 4 - The Magnitude, Probability, and Deterrent impact can be improved if consumers' knowledge is improved.

979 The warranty and the affect of the sanction are jointly responsible for the consumer's view of the deterrent as being "valuable." Independently, the probability of a sanction being imposed on a consumer helps mitigate whether the consumer's view of that sanction is likely to deter the consumer's conduct. Interestingly, both of these inquiries for the consumer- "whether the warranty is valuable" or "whether the loss of warranty is likely" - are capable of being controlled by the manufacturer. Indeed, as consumer information is improved, their decisions will likely become more concrete and create greater probabilities of likely or unlikely sanctions, valued or unvalued services.

${ }^{131}$ (N) Magnitude for Liability -4.75 ; (f) Probability of liability - 1.65; (d) impact of deterrent $=4.84$.

${ }^{132}$ (N) Magnitude for Liability - 3.99; (f) Probability of loss of warranty - 6.35; (d) impact of deterrent $=3.16$

${ }^{133}$ (N) Magnitude for Liability - 3.99; (f) Probability of loss of warranty - 6.35; (d) impact of deterrent $=3.16$. 
980 The respondents in the survey seem to indicate that they were unaware of certain terms or sanctions presented in the warranty. Question 10 asked respondents: "Have you ever read the Apple iPhone or iPod warranty." $11.5 \%$ indicated that they had read one or both of the warranties, while $85.8 \%$ indicated that they had not read either warranty. Question 11 asked respondents: "Were you aware that the Warranty provisions for the Apple iPhone include the following statements: "Important. Do not open the hardware product. Opening the hardware product may cause damage that is not covered by this warranty. Only Apple or an authorized service provider should perform service on this hardware product." $24.3 \%$ indicated that they were aware that the warranty had this provision, whereas $73.0 \%$ indicated that they were not aware.

\$81 Question 12 asked respondents, "[i]s the substance of the provision recited in question 11, something you would expect to find in a warranty provision for Apple's iPhone, even if you had never read the provision prior to this survey." $73 \%$ of the respondents indicated that they would expect a similar provision in the apple warranty, while $23.6 \%$ indicated that they would not expect such a provision.

982 These findings are not surprising in themselves, for only $18.2 \%$ of the participants indicated owning an Apple iPhone. However, the number of people that have read an iPhone or iPod warranty was significantly less $(11.5 \%)$. Moreover, given that the question included those that have read the iPod warranty, it is probable that few people read Apple's warranty who were actually impacted by it.

983 Thus, one control that Apple could impose is the creation of better knowledge of their warranty coverage. This may be moot, however, if that knowledge would confirm that consumers are not losing much by forfeiting their warranty. Moreover, this finding probably does not impact iPhone users that modify their iPhone simply for the sport of doing so.

984 All of these observations demonstrate that there is a real question of whether Apple's current warranty can be a successful deterrent against piracy. The last observation suggests that consumers at the current moment do not deem Apple's limited warranty a real loss when compared to the gains that hacking the iPhone might allow them to reap.

985 It is important to note that the survey is inconclusive at this point. For example, Apple might see significant gains by increasing consumer knowledge of the current warranty, increasing the value of the warranty, or increasing knowledge of Apple's commitment to preserve its "rights" through consumer litigation. However incomplete the data may be, two conclusions are appropriate: 
986 First, the threat of consumer litigation is not likely to deter consumer behavior when consumers do not deem that threat to be probable. Perhaps Apple can raise the stakes of making its threat more probable by selectively litigating certain issues, or by broadly announcing its intent to litigate. ${ }^{134}$ At the moment of distributing this survey, Apple had done neither.

987 Second, the participants indicated that a warranty with a betterknown value can have nearly the same impact factor as the threat of consumer litigation, and when considering probabilities, warranties result in greater rates of deterrence. Naturally, the consumer's perception of the significance of warranty improvements would be a changing condition that varies from consumer to consumer. Whether the benefit is one of additional coverage time, or increased product coverage, the participants in this survey were responsive to some value-added warranty as a deterrent to jailbreaking an Apple iPhone.

\section{CONCLUSION}

988 The first sale doctrine takes away the right to control the use of goods after they sold to consumers. In order to maximize their profits, companies must utilize alternatives to copyright and patent law to protect their intellectual property. The law of warranty presents bountiful possibilities if sellers and manufacturers offer a warranty that consumers would be remiss to lose. The empirical data in this survey suggests that a large number of consumers would be deterred from engaging in piracy behavior if they believed the warranty they were losing was valuable. The knowledge of a valuable warranty requires the company to create better knowledge of its warranty and subsequent limitations for consumers. Companies that create such knowledge can expect to see a real dent in piracy of their technology and as a result a better after-sale revenue stream.

\footnotetext{
${ }^{134}$ For example, consider the human behavioral studies that indicate that people's decisions are influenced by media discussion. Perhaps Apple is able to deter a certain segment simply by widely publicizing that they intend to pursue a litigation remedy, even if they have no actual intent to do so.
} 